\title{
Agricultural Drought Risk Assessment: A Spatial Analysis of Hazard, Exposure, and Vulnerability in Zacatecas, Mexico
}

\author{
David Ortega-Gaucin ${ }^{1, * \mathbb{D}}$, Jesús A. Ceballos-Tavares ${ }^{1}{ }^{\mathbb{D}}$, Alejandro Ordoñez Sánchez ${ }^{2}$ \\ and Heidy V. Castellano-Bahena ${ }^{1}$ (D) \\ 1 Instituto Mexicano de Tecnología del Agua, Paseo Cuauhnáhuac 8532, Col. Progreso, Jiutepec 62550, Mexico; \\ jesus.ceballos@posgrado.imta.edu.mx (J.A.C.-T.); heidy.castellano@posgrado.imta.edu.mx (H.V.C.-B.) \\ 2 Independent Researcher, Jiutepec 62550, Mexico; ordoezale@gmail.com \\ * Correspondence: dortega@tlaloc.imta.mx; Tel.: +52-777-329-3600 (ext. 674)
}

Citation: Ortega-Gaucin, D.;

Ceballos-Tavares, J.A.;

Ordoñez Sánchez, A.;

Castellano-Bahena, H.V. Agricultural

Drought Risk Assessment: A Spatial

Analysis of Hazard, Exposure, and

Vulnerability in Zacatecas, Mexico.

Water 2021, 13, 1431. https://

doi.org/10.3390/w13101431

Academic Editors: Hemant Ojha,

Nick Schofield and

Rachael Mcdonnell

Received: 23 April 2021

Accepted: 18 May 2021

Published: 20 May 2021

Publisher's Note: MDPI stays neutral with regard to jurisdictional claims in published maps and institutional affiliations.

Copyright: (c) 2021 by the authors. Licensee MDPI, Basel, Switzerland. This article is an open access article distributed under the terms and conditions of the Creative Commons Attribution (CC BY) license (https:/ / creativecommons.org/licenses/by/ $4.0 /)$.

\begin{abstract}
Drought is one of the major threats to water and food security in many regions around the world. The present study focuses on the evaluation of agricultural drought risk from an integrated perspective, that is, emphasizing the combined role of hazard, exposure, and vulnerability to drought. For this purpose, we used the Mexican state of Zacatecas as a case study. This state is one of the most vulnerable to the adverse effects of agricultural drought in the country. The proposed method includes three stages: first, we analyzed the risk of agricultural drought at the municipal scale using the FAO Agricultural Stress Index System (ASIS) in its country version (Country-Level ASIS) and also determined a Drought Hazard Index (DHI). Subsequently, we conducted a municipal assessment of exposure and vulnerability to drought based on a set of socioeconomic and environmental indicators, which we combined using an analytical procedure to generate the Drought Exposure Index (DEI) and the Drought Vulnerability Index (DVI). Finally, we determined a Drought Risk Index (DRI) based on a weighted addition of the hazard, exposure, and vulnerability indices. Results showed that $32 \%$ of the state's municipalities are at high and very high risk of agricultural drought; these municipalities are located mainly in the center and north of the state, where $75.8 \%$ of agriculture is rainfed, $63.6 \%$ of production units are located, and $67.4 \%$ of the state's population depends on agricultural activity. These results are in general agreement with those obtained by other studies analyzing drought in the state of Zacatecas using different meteorological drought indices, and the results are also largely in line with official data on agricultural surfaces affected by drought in this state. The generated maps can help stakeholders and public policymakers to guide investments and actions aimed at reducing vulnerability to and risk of agricultural drought. The method described can also be applied to other Mexican states or adapted for use in other states or countries around the world.
\end{abstract}

Keywords: agricultural drought; integrated drought risk assessment; vulnerability; VHI; CountryLevel ASIS; food security

\section{Introduction}

Drought is one of the most complex natural phenomena and one of the most harmful to populations throughout the world [1]. This slow-developing phenomenon is due in part to natural climate variability and has negative impacts on around $60 \%$ of the global agricultural and livestock sectors [2]. Due to their adverse effect on food production and access to environmental resources (i.e, water, wildlife), droughts endanger the lives and sustenance of millions of families, especially in rural environments.

However, as a result of the complexity of the phenomenon and the diversity of criteria used by researchers to characterize it, a universally accepted definition of drought is unviable [3]. However, specialized literature differentiates types of drought according to the types of impact caused by the phenomenon. Drought is approached from meteorological, hydrological, agricultural, and socioeconomic points of view (e.g., [4-6]). According to a 
widely accepted and widespread conceptual model [4,7], these types of droughts generally occur in a particular sequence: climatic variability leads to a precipitation deficit resulting in meteorological drought; the former, combined with high temperatures and low relative humidity, results in increased evapotranspiration, which leads to agricultural drought, i.e., a soil moisture deficit results in reduced crop yield or total loss. Hydrological drought occurs when a precipitation deficit persists over time and is combined with pressure on surface and groundwater supplies due to human demand, which results in a considerable reduction in the water supply to streams, lakes, reservoirs, and aquifers. Socioeconomic drought is associated with the impact of an inadequate supply of economic goods as a result of meteorological, agricultural, and hydrological drought. Thus, the different types of drought are all consequences of a precipitation deficit or meteorological drought. When agricultural and hydrological droughts persist over a long time, a series of economic, social, and environmental impacts tend to follow [8].

In Mexico, droughts pose a serious threat to water and food security. This risk has been confirmed during the many droughts recorded throughout the country's history [9-11], particularly in the recent past; for instance, the most severe drought period in the country in 70 years, in terms of its negative effects on different socio-economic sectors, took place between 2011 and 2012 [12,13]. This drought affected more than $80 \%$ of the national territory and caused the loss of more than 800 thousand hectares of crops; it had adverse effects on 1.3 million livestock (mainly cattle) [14] and caused serious water shortages in cities and rural communities in the most arid and vulnerable regions in the country. Climate models for the twenty-first century predict even harsher scenarios $[15,16]$.

Given that the agricultural sector is essential for Mexico's food security, the impact of drought on agricultural production has received increasing attention in recent years [17]; moreover, agriculture is an essential economic activity in the country's rural areas, home to $22 \%$ of the national population [18]. Seventy-nine percent of cultivated surface area in the state's production units is rainfed (25.6 million hectares), while the remaining $21 \%$ is irrigated (6.8 million hectares) [19]. In general, the first economic sector affected by drought is rainfed agriculture because it depends entirely on rainwater for production, which makes it highly vulnerable to meteorological drought. This type of agriculture is practiced mostly by low-income farmers, the first among society to feel the effects of drought. They are small producers who, with their work and that of their families, achieve just enough production to support themselves, rarely more than that. In the event of a drought, their plants fail to germinate or wither and die. In any case, they are unable to harvest: the first step into disaster [20].

For its part, the Mexican government has considered making food production one of the main drivers for economic recovery and growth at the state, regional, and national levels. This makes guaranteeing self-sufficiency and food security in the country a priority because these actions can have a profound impact on the country's national sovereignty and security [21]. Therefore, it is very important to carry out an accurate assessment of the threats to food production, among which is the risk of agricultural drought-especially rainfed agriculture-in the different states and regions in the country to provide public policymakers with the knowledge to guide public programs aimed at preventing and mitigating the impact of drought in the near future.

Understanding the risk factors associated with agricultural drought and the ways in which their impact materializes is crucial to the improvement of evaluations and to identify and plan the best alternatives to reduce the risk. It should be taken into account that the risk of disaster due to drought depends not only on the degree to which rainfall has decreased and the temporal or geographical extent of the phenomenon, but also on the vulnerability of production systems and the farmers' ability to cope with drought, which in turn is affected by local socioeconomic, production, and technological conditions $[11,20]$. As a type of hazard, drought is a product of climate-related factors such as rainfall, moisture deficiency, and temperature, and is also influenced by anthropogenic alterations in hydrological processes and the physical environment [22]. The mechanisms 
that lead to drought cannot be attributed solely to climate-related drivers; therefore, considering existing socio-economic conditions and using a perspective that combines human and environmental systems is essential [23,24]. However, these fields are usually studied independently, ignoring the complex feedback between natural and human factors [22].

Thus, numerous studies around the world have focused on the phenomenon of drought from a purely physical perspective using different types of indices (meteorological, hydrological, or related to vegetation or soil humidity) created to characterize and monitor hazard $[5,6,25]$, but far fewer studies have analyzed drought from a socioeconomic perspective, that is, from the point of view of vulnerability [26-28]. Nevertheless, in recent years, the interest in studying drought risk from an integrated perspective has been growing, emphasizing the combined role of drought hazard (the intensity, frequency, and duration of the phenomenon) and exposure and vulnerability to drought (a series of socio-economic, physical, and environmental factors present in the analyzed system) [28,29]. Interesting research has been carried out in recent years in different parts of the world focusing specifically on agricultural drought risk (i.e., [30-36]).

In the case of Mexico, there are very few comprehensive assessments of drought risk using spatially and temporally consistent information on the possible hazard complemented by exposure factors and drought vulnerability [37]. The vast majority of research on drought carried out in the country has focused on evaluating the meteorological drought hazard based on rainfall records obtained from weather stations (i.e., [38-42]). However, weather stations are not evenly distributed in the country, and fewer and fewer stations remain operational due to a lack of maintenance budget and personnel, which is why historical climatological records are not spatially or temporally consistent and they must be subjected to quality control, homogenization, and data filling processes [43,44]. Given these circumstances, and despite the enormous potential of remote-sensing techniques based on satellite imagery to monitor drought, remote-sensing techniques have rarely been used in the country. These techniques can provide valuable, spatially, and temporally consistent information on the different types of drought in quasi-real-time [33], which is very useful for early warning purposes [45-47]. On the other hand, national studies on vulnerability to drought have been carried out without explicitly defining the type of drought hazard addressed (i.e., [20,48-50]) or by referring to vulnerability to climate change in general (i.e., [51-54]). There is also very little research focused on the risk of agricultural drought in the different states or regions in the country [55-57]. Therefore, it is essential to further advance our knowledge in this field.

In this context, the present study sought to address the gaps described above by using a multidimensional approach to assess agricultural drought risk (focused on rainfed agriculture), which can be applied to the different states and regions in Mexico. The method uses spatially and temporally consistent information on the hazard calculated using vegetation indices obtained from satellite imagery and phenological information about the crops; these data are complemented by socioeconomic and environmental indicators of exposure and vulnerability to drought, and all information is compiled into a municipal drought risk index. We used the state of Zacatecas as a case study and an example of the study method. The state is located in a semi-arid region of national agricultural importance, and it suffers the effects of drought with some regularity [41,42]. For instance, Zacatecas lost 478 million dollars in rainfed agricultural production due to drought in 10 years (2005-2014); 2005, 2009, and 2011 were the most critical, with economic losses of 47\%, $39 \%$, and $63 \%$, respectively [58]. The results of the present study are useful to construct a precise image of the spatial distribution of hazard, exposure, vulnerability, and risk of agricultural drought; this image can be used to make decisions on which prevention and mitigation measures could be implemented to reduce vulnerability and achieve adequate risk management. 


\section{The Concept of Risk and Its Reference Framework}

The concept of risk, associated with the idea of an uncertain future, has always been present in human societies [59]. The Office of the United Nations Disaster Relief Coordinator (UNDRO) used two concepts of risk that are still the basis for current definitions: Specific risk (Rs), which refers to the degree of expected losses due to the occurrence of a particular event, is calculated as a function of hazard and vulnerability, and Total risk $(R t)$, which refers to the number of human casualties and injuries, property damage, and adverse effects on economic activity due to a disaster, that is, a product of specific risks $(R s)$ and elements at risk (E) [60]. Subsequently, the United Nations Office for Disaster Risk Reduction (UNISDR) defined risk as the possible losses that could result from a disaster in terms of lives, health conditions, livelihood, and availability of goods and services in a particular community or society at a specific time in the future [61]. More recently, the Intergovernmental Panel on Climate Change (IPCC) has referred to risk as the possible adverse consequences of situations where something of value is endangered and the outcome is uncertain. This definition recognizes the diversity of values: life; means of subsistence health; ecosystems and species; economic, social, and cultural assets; services (including environmental services); and infrastructure [62].

The drought risk analysis described in the present study is based on the classic riskassessment approach proposed by the IPCC [62], stating that risk is a function of three components: hazard, exposure, and vulnerability (Figure 1). From a meteorological point of view, a hazard is, in general, a weather or climate condition (frost, hailstorms, drought, hurricane, torrential rain, etc.) that can have adverse effects on a vulnerable system, and given its random nature, it is measured as the probability of a particular phenomenon to occur [63]. In the present study, we focused on the phenomenon of drought hazard and its impact on rainfed agricultural areas; therefore, we will refer to agricultural drought hazard as the probability of a drought event to occur within a definite timeframe, in a specific space, and with enough intensity to cause damage (partial or total losses) to rainfed crops. Exposure is defined as the presence of people, properties, livelihoods, and systems prone to potential damage and loss. In the context of agricultural drought, exposure includes the crops, the farmers, and other people working in the agricultural sector who are at risk of losing their jobs, food sources, or income [64]. Vulnerability refers to someone's or something's propensity to be adversely affected; it includes various concepts and elements, including sensitivity or susceptibility to damage and lack of adaptive capacity. In the case of agricultural drought, vulnerability describes how sensitive (susceptible) soil and agricultural production are, as well as the people who depend on exposed agriculture, to the impacts of drought hazard (susceptibility), and which resources can be used by people or the agroecosystem to reduce the impact of the hazard (coping capabilities) [65].

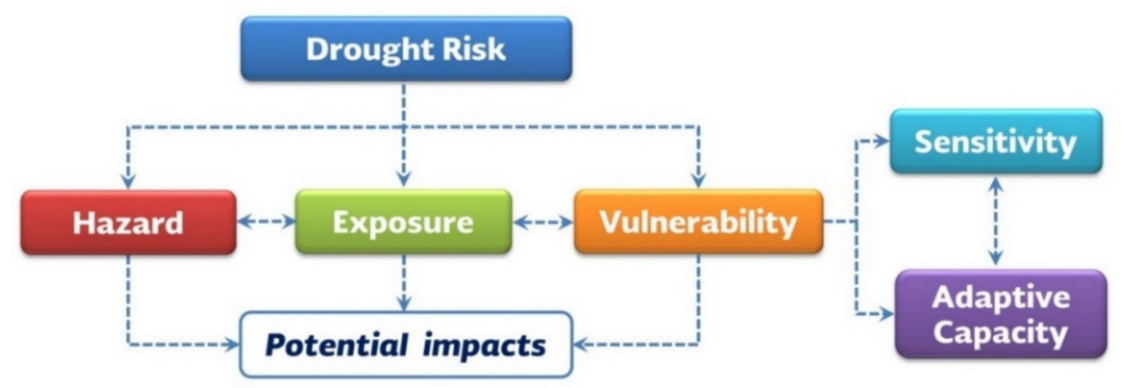

Figure 1. Classic approach to drought risk assessment.

Under this approach, the magnitude of a drought event, in addition to exposure and vulnerability data, can be used to determine the potential impact of a specific drought event [66]. In other words, drought risk can be expressed mathematically by the following functional relationships:

$$
R=f(H+E+V)
$$




$$
V=f(S-A C)
$$

where $R=$ Drought risk, $H=$ Hazard $E=$ Exposure, $V=$ Vulnerability, $S=$ Sensitivity, and $A C=$ Adaptive capacity.

Several risk assessments have been carried out using the conceptual framework described above and different methods to quantify and analyze the concepts involved (e.g., [29,32]). Drought hazard is often evaluated using historical, hydrological, or climate information to characterize the frequency, severity, duration, and geographical extent of the phenomenon and determine its probability of occurrence using a series of indices designed to analyze different types of drought [25]. In the case of agricultural drought, soil moisture and vegetation health indices are usually obtained and processed by remote sensors (satellite images) $[46,47]$. Methods based on socioeconomic and environmental indicators are the most widely used to evaluate exposure and vulnerability [20]; these indicators are often combined to produce composite indices representing the different components of vulnerability, exposure, and risk [28]. This methodological approach contributes to understanding the multidimensional nature of these variables better; this is especially useful in decision-making processes aimed at managing risk [20].

Thus, based on this reference framework, we determined hazard, exposure, vulnerability, and risk indices for each of the municipalities in the state of Zacatecas and generated the corresponding state maps using the materials and methods described below.

\section{Materials and Methods}

\subsection{Study Area}

The state of Zacatecas is located in Mexico's north-central region, in the Mexican Plateau physiographic region (Figure 2a); it has a surface area of $75,284 \mathrm{~km}^{2}$, which represents $3.8 \%$ of the national territory, and is divided into 58 municipalities (Figure $2 b$ ), whose main characteristics (area, population, rainfed agricultural area) are presented in Table S1 (Supplementary Materials). The state is characterized by its arid zones (dry or semidry climates) covering more than $75 \%$ of its territory (Figure 2c). Average annual rainfall varies from $300 \mathrm{~mm}$ per year in the north to $800 \mathrm{~mm}$ per year in the south (Figure 2d). These climatic conditions contrast with those of the southern and southeastern states of the country, which are characterized by warm and rainy climates, with rainfall ranging between 1000 and $3000 \mathrm{~mm}$ per year. Therefore, the state of Zacatecas is highly vulnerable to the presence of drought and has been one of the most affected by this phenomenon over the past years. Agriculture and stockbreeding are the 2 main economic activities in Zacatecas; $79 \%$ of its surface area presents favorable conditions for these activities (Figure 2e). An average of 1.24 million hectares of crops was sown from 1985 to 2019, 88\% of which (1.09 million hectares) were rainfed, and the remaining $12 \%$ ( 0.15 million hectares) were irrigated. Of the total area devoted to crops, $57.9 \%$ is used to grow beans, making the state the first bean producer in the country. This is followed by maize, with $27.3 \%$ of the planted surface, forage oats, with $4.9 \%$; chili, with $2.6 \%$ - and the remaining percentage $(7.3 \%)$ is distributed among other crops such as wheat, sorghum, and fruits [67]. 


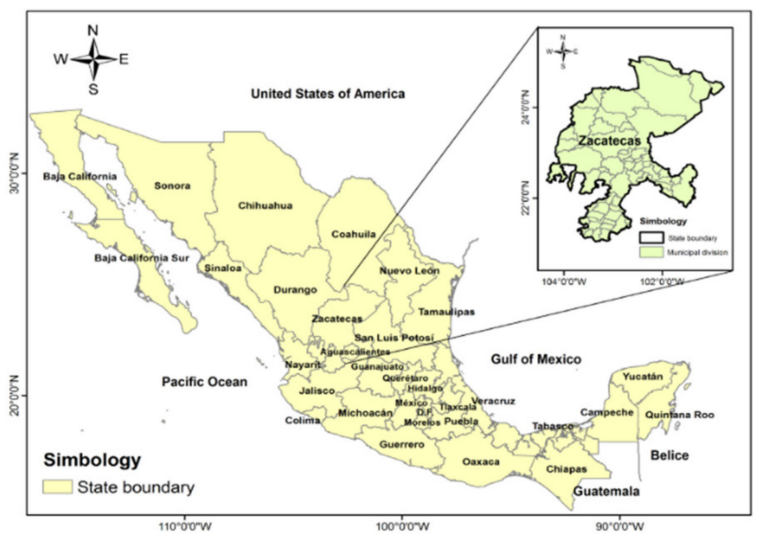

(a)

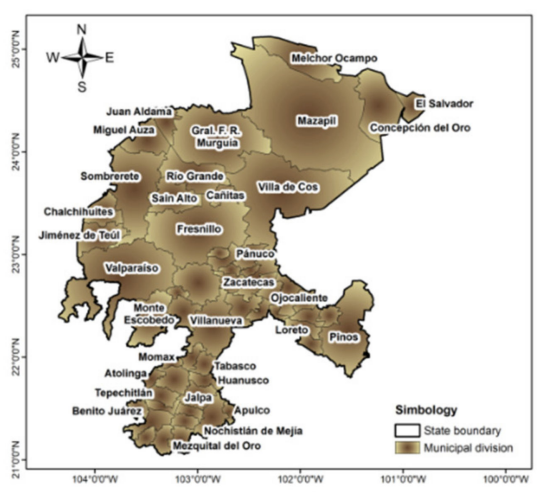

(b)

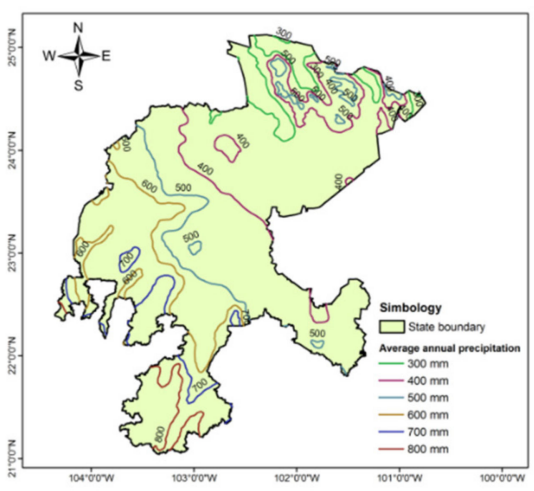

(d)

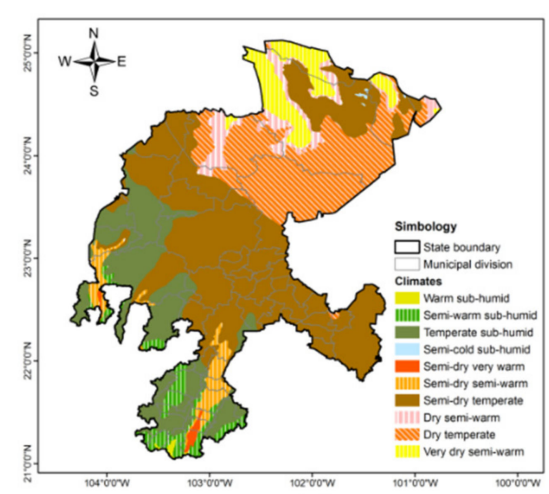

(c)

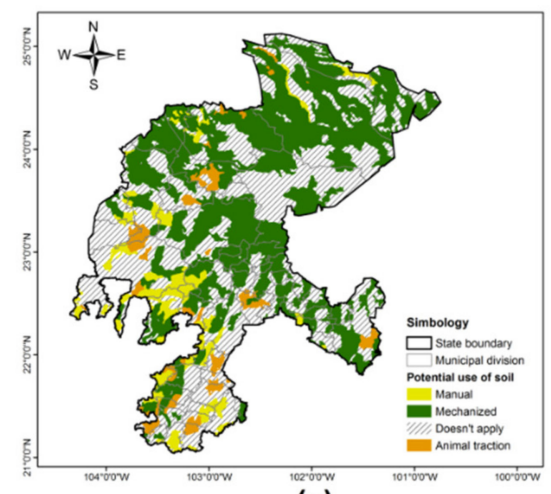

(e)

Figure 2. Maps of the state of Zacatecas: (a) Geographical location in Mexico; (b) Municipal division; (c) Types of climate; (d) Annual isohyets; (e) Potential soil use. Source: Prepared by the authors based on [68].

\subsection{Methodology}

The proposed method was conducted in 3 stages (Figure 3). First, we analyzed agricultural drought hazard at the municipal level using the Agricultural Stress Index System (ASIS), specifically, its country version (Country-Level ASIS), which is based on satellite information and was developed by the UN's Food and Agriculture Organization (FAO), which supports countries in the monitoring and early warning of drought affecting agriculture [69]. Subsequently, we assessed exposure and vulnerability to drought based on a set of socioeconomic and environmental indicators obtained from databases operated by recognized Mexican institutions and combined these indicators using an analytic procedure to generate exposure and vulnerability indices [20,50]. Finally, we determined agricultural drought risk indices utilizing a weighted addition of hazard, exposure, and vulnerability indices. The following sections describe these phases in detail. 


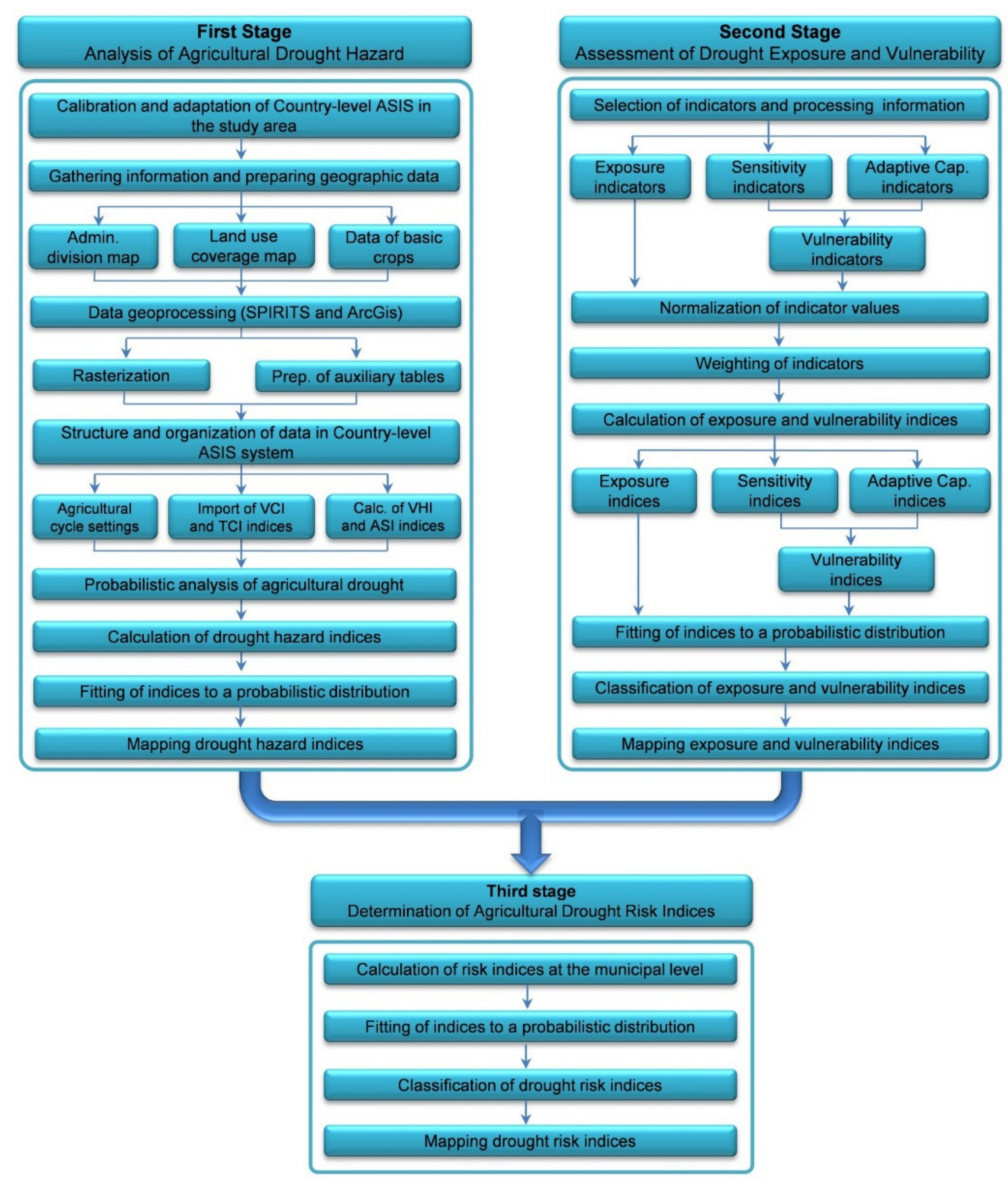

Figure 3. Methodological workflow to determine hazard, exposure, vulnerability, and agricultural drought hazard indices.

\subsubsection{Agricultural Drought Hazard Analysis}

Having recognized that the problem of drought is significant for agriculture due to its impact on world food security, the FAO has developed a global tool based on satellite imagery to monitor and detect agricultural areas where crops could be affected by drought. This tool is called the ASIS system and is operational in FAO-Rome at the global level as technical support for the Global Information and Early Warning System (GIEWS) [69]. Based on the general methodological principles of the Global ASIS system, and with the purpose of supporting countries to strengthen their agricultural drought-monitoring and early-warning systems, the FAO developed a Country-Level ASIS, which simulates the analysis that a remote sensing expert would carry out and simplifies the results in the form of maps for end-users [70]. The tool is freely accessible and should be calibrated using field information (maps of current soil use, sowing dates, length of crop cycle, and crop coefficients); it is also more accurate than the global tool for detecting water stress in crops. Drought monitoring is continuous; FAO provides free satellite data every 10 days, an ideal period for monitoring annual crops because it considers the amount of water in the soil (probability calculations are based on a historical record of 35 years of satellite images, also freely available from FAO). The final results of the Country-Level ASIS are summarized in maps, which can be easily interpreted by decision-makers so that drought prevention and mitigation activities can be timely implemented [70].

- Fundamentals of Global ASIS and Country-Level ASIS

The ASIS tool uses the Vegetation Health Index (VHI) to assess agricultural drought $[69,70]$. This index is the result of work carried out by Kogan [71,72] in the National Oceanic and Atmospheric Administration (NOAA) in the United States and has been successfully applied in numerous studies and environmental conditions around the world, including Asia, Africa, 
Europe, and the Americas. It represents one of the first attempts to monitor and detect the effects of drought in agriculture using data obtained by remote sensing [25]. To obtain this information, satellite images in the visible and near-infrared channels obtained by the Advanced Very High-Resolution Radiometer (AVHRR) sensor are used to detect and classify vegetation stress caused by drought.

The VHI is a combination of the Vegetation Condition Index (VCI) and the Temperature Condition Index (TCI). The VCI is in turn derived from the Normalized Vegetation Difference Index (NDVI) [73]. The latter is an indirect measure of primary production as a function of its relationship with photosynthetically active radiation [74]. The VCI locates the NDVI between the maximum and minimum of the historical series of satellite information and is expressed as

$$
V C I_{i}=\frac{N D V I_{i}-N D V I_{\min }}{N D V I_{\max }-N D V I_{\min }}
$$

where $V C I_{i}=$ Vegetation Condition Index for $10 i(10$-day period $i), N D V I_{i}=$ Normalized Vegetation Difference Index for $10 i, N D V I_{\max }=$ Absolute maximum value of the historical series of NDVI indices, and NDVI $I_{\min }=$ Absolute minimum value of the historical series of NDVI indices.

The VCI was designed to separate the climate component from the ecological component that affects the value of the NDVI vegetation index. In general, VCI captures precipitation dynamics better than NDVI, especially in heterogeneous geographical areas. VCI reflects not only the spatial and temporal variability of vegetation but also quantifies the impact of climate on vegetation $[73,75]$.

For its part, the Temperature Condition Index (TCI) is calculated in a similar way as the VCI, but it relates the temperature estimated by the infrared band of the AVHRR sensor (channel 4). Kogan [71] proposed this index to remove the confounding effect of clouds in the satellite evaluation of vegetation conditions due to the fact that channel 4 of the AVHRR sensor is less sensitive to water vapor in the atmosphere than to visible light. High temperatures in the middle of the cropping cycle indicate unfavorable or drought conditions, whereas low temperatures indicate favorable conditions [71]. Consequently, the expression of the index is

$$
T C I_{i}=\frac{T_{\max }-T_{i}}{T_{\max }-T_{\min }}
$$

where $T C I_{i}=$ Temperature Condition Index for $10 i ; T_{i}=$ Temperature of $10 i ; T_{\max }=$ Maximum absolute temperature value in historical series; $T_{\min }=$ Minimum absolute temperature value in historical series.

Finally, the Vegetation Health Index (VHI) is calculated based on these 2 indices, which is mathematically expressed as follows:

$$
V H I_{i}=a V C I_{i}+b T C I_{i}
$$

Thus, VHI is the additive combination of VCI and TCI for each 10-day period (10 i), with values varying between 0 and 1 . Parameters $a$ and $b$ are the weighting coefficients $(a+b=1)$. In approximately normal conditions, vegetation is more sensitive to humidity during leaf formation and to temperature during flowering [70]. According to [76], since moisture and temperature contribution during the crop cycle is currently unknown, the share of 10-day period VCI and TCI was set equally $(a=b=0.5)$ in Global ASIS. However, in some studies, different weighting coefficients were assigned to VCI and TCI; for example, [75] determined the weights based on the correlation between VCI and TCI with corn yield anomalies. In the present study, we carried out a preliminary correlation study to determine the values of the coefficients that more accurately represented agricultural drought conditions in the studied area, and we found that these values were $a=0.7$ and $b=0.3$ [77]; therefore, we used these values when calculating the VHI index. 
This index is the most elementary indicator and the main entry for the Country-Level ASIS tool, and it is available by pixel and 10-day period. The basic idea of the index is as follows: the lower the observed VCI (relative lack of green color in vegetation) and the higher the observed TCI (relatively warm temperature), the lower the VHI. Low VHIs are indicators of drought, especially when they persist for long periods of time [74].

Based on the VHI, the Country-Level ASIS introduces the Mean Vegetation Health Index (M-VHI) [78]. To incorporate different crop phenological sensitivities to water stress over the crop-growing phases, crop coefficient $\left(\mathrm{k}_{\mathrm{c}}\right)$ [79] values were used for weighting the temporal integration of VHIs during the crop-growing season (denoted as $\mu \mathrm{VHI}$ ):

$$
\mu V H I=\sum_{d=1}^{n} k_{c}(d) * V H I(d)
$$

where $\mu \mathrm{VHI}$ is the temporal weighted VHI by $k_{c}$, with values ranging from 0 to $1 ; d$ is the season in a year when a crop grows (season is defined by the start of the season (SOS) and end of the season (EOS)); and $k_{c}$ is the crop coefficient, a series of values specific to the crop of interest through its growing season.

$\mathrm{M}-\mathrm{VHI}$ results are obtained from the average of these integrated $\mu \mathrm{VHI}$ values (Equation (6)) within the spatial analysis dimension, which can be an administrative division or any specific area of interest [76]. Based on these data, the Country-Level ASIS evaluates the severity (intensity, duration, and spatial extent) of agricultural drought and presents final results at the administrative unit (state, municipality, district) or agroecological level, which allows for comparisons with agricultural statistics in the studied area $[70,80]$.

The first step of the Country-Level ASIS is to calculate the M-VHI as crop development progresses (time scale), which allows for the evaluation of intensity and duration of dry periods within the crop cycle at the pixel level (see Figure 4a). The system is based on a historical record of 35 years (1984-2019) of satellite information on VCI and TCI indices. This record period guarantees that the series contains extreme drought events, which is often not the case when using short series. To achieve this series of satellite data, an "intercalibration" study was carried out using data produced by the NOAA-AVHRR (available since 1984 and has a 16-km resolution) and METOP-AVHRR (available since 2007 and has a 1-km resolution) satellites $[70,76,78]$.

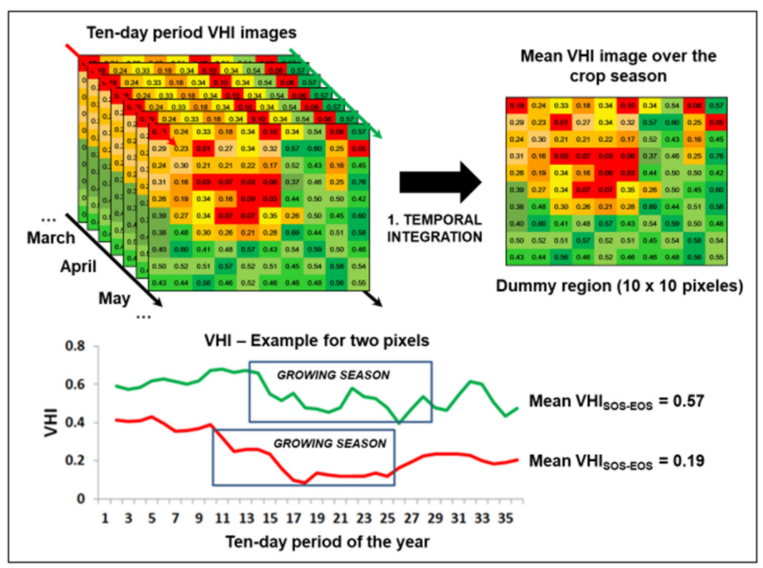

(a)

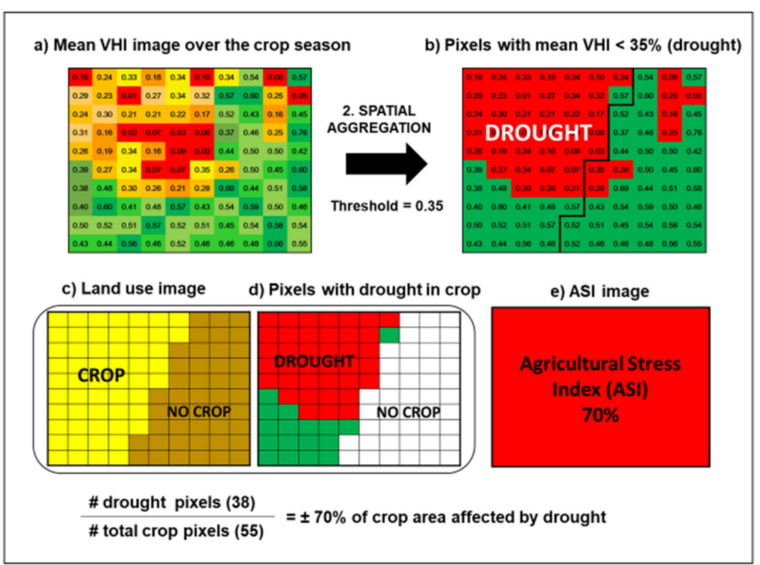

(b)

Figure 4. Graphic representation of the temporal and spatial integration of the VHI in a dummy region of 10x10 pixels for calculating the Agricultural Stress Index (ASI): (a) The M-VHI per pixel for the crop cycle was obtained based on a historical series of VHI images of the study area taken every 10 days; subsequently, (b) A spatial integration using only the cultivated area was carried out based on the M-VHI raster image. The ASI index is the percentage of the cultivated area within the administrative area with M-VHI values lower than 0.35. All the pixels in the administrative area acquire the ASI value. Source: Adapted from [70,80]. 
The second step consists of calculating the percentage of agricultural area affected by drought (pixels with $\mathrm{M}-\mathrm{VHI}<0.35$, a value identified as critical in previous studies $[71,74,75]$ ) to evaluate the spread of the phenomenon (spatial scale) (see Figure $4 \mathrm{~b}$ ). Therefore, the tool determines the Agricultural Stress Index (ASI), an indicator of anomalies in vegetation growth and potential droughts in cultivated areas during a given agricultural cycle $[70,76,78]$. The index represents the percentage of pixels of a specific type of crop or land use within each administrative area affected by drought throughout the agricultural cycle. Pixels with an M-VHI value below the $35 \%$ threshold are identified as drought sites. When more than $50 \%$ of the cultivated area is affected by drought, an extreme drought event can be assumed to be taking place along with a serious impact on food security [74]. Figure 4 illustrates the ASI calculation using a dummy example of a $10 \times 10$ pixel region.

Following the recommendations from FAO experts, the calibration and implementation of the system require the definition of a study area of agricultural importance that is prone to suffering the effects of drought with some frequency. Ideally, the study area can be, for example, a state, a watershed, an irrigation district, or a rural development area. In this case, we took the first option and selected the state of Zacatecas as the study area, which meets the requirements mentioned above.

- Calibration and adaptation of Country-Level ASIS in the study area

The protocol to calibrate and adapt the Country-Level ASIS was carried out based on recommendations by [80-82], who describe the necessary steps for the implementation of the system in a given country (or part of a country) and the necessary calibration to achieve accurate monitoring and a probabilistic prediction of agricultural drought. The method is described in the following paragraphs.

(a) Information gathering and geographic data preparation

System input data consist of 3 basic types: vector data (shapefile type), raster data (georeferenced images), and data tables. To use them with the Country-Level ASIS, it is first necessary to carry out conversion processes to obtain the required image formats. The Country-Level ASIS performs all parameter and output data calculations using raster files.

The required information is as follows: (a) Administrative division map (states, municipalities, rural development districts, etc.); (b) Land use coverage map (crop mask); (c) Data on the phenology of selected basic crops (sowing and harvesting dates and cultivation coefficients).

The administrative division map for Zacatecas was obtained from the Mexican Geostatistical Framework prepared by INEGI [68]; the map is a vector file (shapefile) that contains information on state and municipal geostatistical areas, as well as polygons of urban and rural areas, among other data. In this case, the administrative unit of interest is the municipality, since statistical information on agricultural production is available at that level; therefore, only the municipal division was employed, as shown in Figure $2 \mathrm{~b}$ (described in the previous section). This file was converted to raster format by geoprocessing using SPIRITS (Software for the Processing and Interpretation of Remotely Sensed Image Time Series) per the procedure described by [81].

The land use/cover map (crop mask) is considered the fundamental input for monitoring agricultural drought because it pinpoints the location of the basic crops being monitored. The crops considered by the present study were rainfed beans and grains (maize, wheat, and sorghum); according to the FAO, these crops are important for food security to guarantee an elemental diet. The crop mask for the study area was provided in vector format (shapefile) by SIAP [83]; it was converted to a raster format (similar to the administrative division map) to create the map shown in Figure 5. 


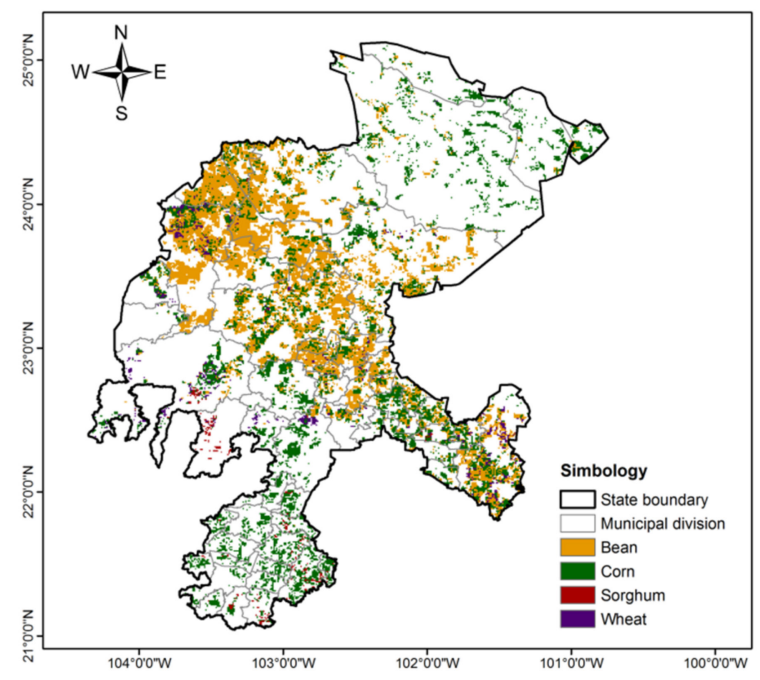

Figure 5. Mask of rainfed basic crops for the study area.

As can be appreciated in this map, the predominant crop in the state of Zacatecas is bean; this produce is planted mainly in the central part of the state, and to some extent, in the northwest and southeast parts of the state. Grain maize is mainly grown in the southeast; however, scattered cultivation areas can be observed in the center, north, and south. Grain sorghum and grain wheat are grown on a small scale in the state's central and southern parts. The Country-Level ASIS can be used for the independent analyses of agricultural areas where, for example, maize or bean is grown.

The phenology of the selected crops refers to data on crop coefficients $\left(k_{\mathrm{c}} s\right)$ and sowing and harvesting dates. $\mathrm{k}_{\mathrm{C}} \mathrm{s}$ are used to assign a different weight to the different phenological phases. For example, in cereals, the phenological phase of flowering and grain filling is more sensitive to water stress; therefore, this phase is given a high $\mathrm{k}_{\mathrm{c}}$ value so that the phase acquires a predominant weight when integrating the VHI. The FAO recommends using general $\mathrm{k}_{\mathrm{c}}$ values published in the literature when lysimeter studies determine that $\mathrm{k}_{\mathrm{c}} \mathrm{s}$ are unavailable for a given area. The present study used values indicated in FAO Irrigation and Drainage Paper No. 56 [84] as shown in Table 1.

Table 1. Crop coefficients $\left(\mathrm{k}_{\mathrm{c}}\right)$ for selected basic crops.

\begin{tabular}{|c|c|c|c|c|c|}
\hline No. & Crop & $\mathbf{k}_{\mathrm{c} \text { ini }}$ & $\mathbf{k}_{\mathrm{c} \text { med }}$ & $\mathbf{k}_{\mathrm{c} \text { end }}$ & Max. Height (m) \\
\hline 1 & Bean & 0.4 & 1.15 & 0.35 & 0.40 \\
\hline 2 & Grain maize & 0.7 & 1.2 & $0.60-0.35$ & 2.00 \\
\hline 3 & $\begin{array}{l}\text { Grain } \\
\text { sorghum }\end{array}$ & 0.7 & $1.0-1.10$ & 0.55 & $1.00-2.00$ \\
\hline 4 & Grain wheat & 0.7 & 1.15 & $0.40-0.25$ & 1.00 \\
\hline
\end{tabular}

In addition to crop coefficients (whose values generally vary between 0.3 and 1.2), the sowing and harvesting dates of the crops must be determined based on the duration of each crop's vegetative cycle. These data were obtained from the document prepared by INIFAP [85] and from a report by INEGI [86] on bean cultivation. These dates may vary a few days or weeks depending on the municipality, but the present study considered an average date for all municipalities in the state based on the planting and harvesting periods for the entire state. The Country-Level ASIS requires these dates to be expressed as a 10-day period counted since the first day of the year (i.e., 1-10 January). For instance, if the sowing date for a crop were 25 January, it would be in the third 10-day period of the year, and if it were 5 April, it would be in the tenth 10-day period of the year. Table 2 presents the sowing and harvesting periods of the selected crops expressed as calendar dates and their corresponding average 10-day periods. 


\section{(b) System installation and calibration}

Table 2. Sowing and harvesting dates of basic crops in Zacatecas.

\begin{tabular}{|c|c|c|c|c|c|c|}
\hline No. & Crop & Sowing Period & $\begin{array}{c}\text { Average } \\
\text { Sowing Date } \\
\text { Expressed as a } \\
\text { 10-Day Period } \\
\text { of the Year }\end{array}$ & $\begin{array}{c}\text { Vegetative } \\
\text { Cycle (Days) }\end{array}$ & Harvesting Period & $\begin{array}{c}\text { Average } \\
\text { Harvest Date } \\
\text { Expressed as a } \\
\text { 10-Day Period } \\
\text { of the Year }\end{array}$ \\
\hline 1 & Bean & 15 June-15 July & 18 & 95 & 15 October-15 December & 32 \\
\hline 2 & Maize & 15 June-15 July & 18 & 153 & 15 November-15 December & 33 \\
\hline 3 & Sorghum & 15 June-15 July & 18 & 110 & 15 October-15 November & 30 \\
\hline 4 & Wheat & 15 June-15 July & 18 & 120 & 20 October-20 November & 31 \\
\hline
\end{tabular}

The previously specified calibration protocol [82] indicates that the installation and processing requirements of the Country-Level ASIS include a computer with an ideal hard disk capacity of $10 \mathrm{~TB}$ dedicated exclusively to the agricultural drought monitoring system. The required computer was acquired via an investment expense from the National Council for Science and Technology (CONACYT), and the software was provided free of charge by FAO. The system was installed and calibrated using advice from FAO experts, who provided technical support during the process as well as manuals on how to use the tool. The 35-year historical record (1984-2019) was downloaded via FTP (file transfer protocol) from FAO HQ (Rome); the dataset was updated every 10 days via the same connection. The essential vegetation indices to download were the VCI and TCI indices. These indices were intended to calculate the VHI index, as previously mentioned. Figure 6 presents an example image, including the VCI and TCI indices for the study area.

\section{(c) Probabilistic analysis of agricultural drought}

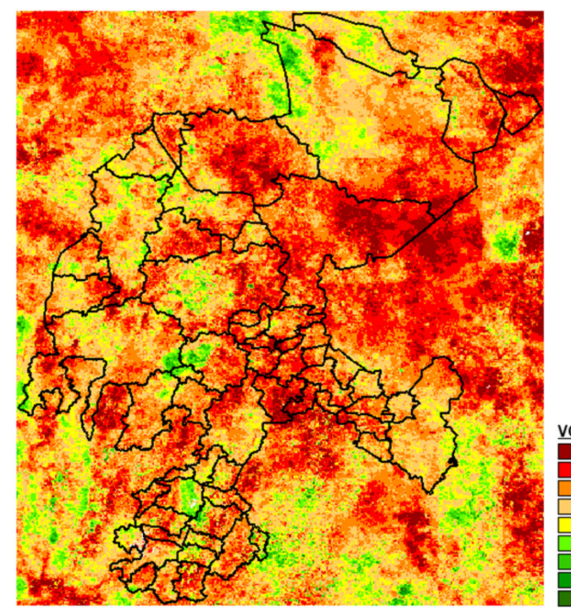

(a)

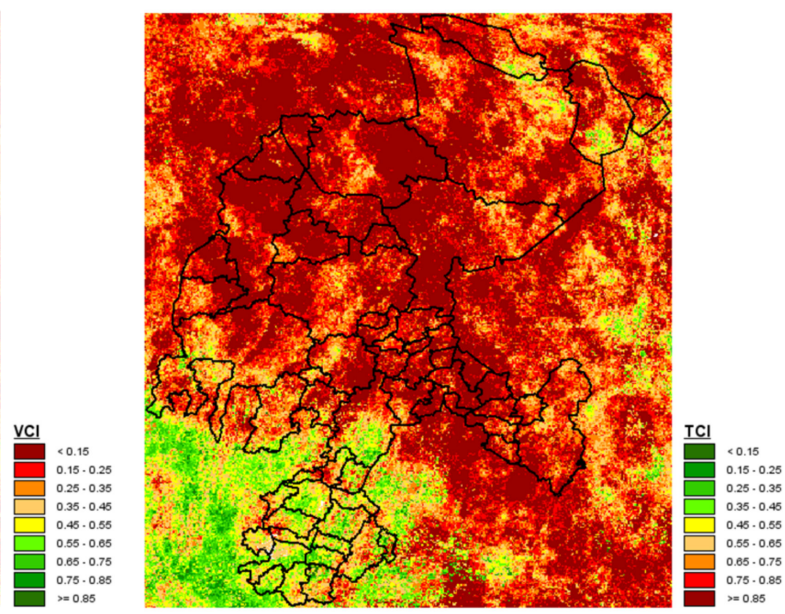

(b)

Figure 6. VCI (a) and TCI (b) indices for the second 10-day period of June 2011.

The ASIS-País system allows for 10-day and annual operations. Ten-day operations are used mainly to analyze drought behavior during the crop cycle and early warning purposes, whereas annual operations are used for historical drought, retrospective, and probabilistic analyses. In this study, we employed annual operations to calculate the ASI index by municipality and by year based on the 35-year historical record (1984-2019). The ASI index's annual operations show the status at the end of the year and the selected agricultural cycle, which in this case corresponds to the spring-summer cycle. Thus, based on the ASI index, we determined the degree of drought hazard (i.e., probability of 
agricultural drought by municipality) as follows: first, we calculated the drought hazard index (DHI) using the following equation:

$$
D H I=\frac{\sum_{i=1}^{n} A S I_{i}}{n}
$$

where ASI is the percentage of cultivated area affected by drought in each municipality (including all selected crops) for a specific year $i$ and $n$ is the total number of recorded years.

After that, we fit a probability distribution function (PDF) to the sample data, i.e., to all calculated DHI values for the state's municipalities. For that purpose, we used the EasyFit ${ }^{\circledR}$ software, which allows for the automatic fitting of more than 50 distributions to the sample data and to select the best model in seconds based on the results of 3 goodness of fit tests: Kolmogorov-Smirnov, Anderson-Darling, and Chi-square. Thus, of all the analyzed PDFs, there were at least 10 that fit well to the sample data, from which we selected the Generalized Extreme Value (GEV) distribution since it is one of the most widely used to model and analyze the risk of extreme natural phenomena [87]. The cumulative distribution function (CDF) of the GEV distribution is

$$
\begin{gathered}
F(x)=\exp \left[-\left(1+k\left(\frac{x-\mu}{\sigma}\right)\right)^{-\frac{1}{k}}\right] \quad \text { for } k \neq 0 \\
F(x)=\exp \left[-\exp \left(-\frac{x-\mu}{\sigma}\right)\right] \rightarrow \text { for } k=0
\end{gathered}
$$

where $k, \mu$, and $\sigma$ represent the shape, location, and scale parameters of the distribution function, respectively. Note that $\sigma$ and $1+k(x-\mu) / \sigma$ must be greater than 0 . The shape and location parameters can take any real value. The resulting PDF for 2 categories of the shape parameter (i.e., whether it is equal to 0 or not) is

$$
\begin{gathered}
f(x)=\frac{1}{\sigma} \exp \left[-\left(1+k\left(\frac{x-\mu}{\sigma}\right)\right)^{-\frac{1}{k}}\right]\left[1+k\left(\frac{x-\mu}{\sigma}\right)\right]^{-\frac{1}{k}} \text { for } k \neq 0 \\
f(x)=\frac{1}{\sigma} \exp \left[-\left(\frac{x-\mu}{\sigma}\right)-\exp \left(-\frac{x-\mu}{\sigma}\right)\right] \quad \text { for } k=0
\end{gathered}
$$

Figure S1 (Supplementary Materials) presents a summary of the results obtained by fitting the GEV distribution to the ASI index data sample. This summary includes PFD and CDF charts; the calculated parameter values $k, \mu$, and $\sigma$; and results of the Kolmogorov-Smirnov, Anderson-Darling, and Chi-squared goodness of fit tests.

Subsequently, we grouped the standardized indices into 5 percentile categories of equal size ( $20 \%$ each); in this way, we defined 5 degrees of drought hazard, as indicated in Table 3 . This classification into 5 categories is taken from our previous work $[20,50]$ because it has the advantage that it allows us to easily display and distinguish the different degrees of hazard that municipalities have when they are represented on a map.

Table 3. Agricultural drought hazard classification categories.

\begin{tabular}{cc}
\hline Degree of Hazard & Value of Percentile \\
\hline Very low & $0<D H I_{i} \leq 20$ \\
Low & $20<D H I_{i} \leq 40$ \\
Moderate & $40<D H I_{i} \leq 60$ \\
High & $60<D H I_{i} \leq 80$ \\
Very high & $80<D H I_{i} \leq 100$ \\
\hline
\end{tabular}


Finally, we developed an agricultural drought hazard map for the state of Zacatecas using the ArcGis ${ }^{\circledR}$ software using the National Geostatistic Framework as a base map [68], which outlines state and municipal divisions.

\subsubsection{Evaluation of Exposure and Vulnerability to Drought}

The procedures used for the construction of municipal indices of exposure and vulnerability to agricultural drought are very similar in both cases and are based on our previous work [20,50]; the only differences are the indicators used in each case and the corresponding index calculation formula, as described below.

- Selection of indicators and information processing

For an index to be easy to use and process, its formulation should rest on a small number of indicators reflecting relevant and guiding aspects of the type of action to be carried out by decision-makers [88]. This set of indicators, by themselves and especially when disaggregated at the local level, could facilitate the identification and orientation of actions to be promoted, strengthened, or prioritized in order to achieve a higher level of safety from hazard. Consequently, a small number of all possible indicators must be selected based on data availability, personal judgment, or previous research [89].

In this study, we took into account previous research when selecting indicators (i.e., $[20,50,54,90,91])$, as well as data validity and direct relevance to the indicators to be measured; however, the determining criterion was that data were open access, available at the municipal level, and based on figures or proportions in databases generated by recognized Mexican institutions [20,37,50], such as the National Institute of Statistics and Geography (INEGI), and the Agri-Food and Fisheries Information Service (SIAP). Therefore, we chose a set of 16 indicators, 6 of which are part of the Drought Exposure Index (Table 4), and the remaining 10 make up the Drought Vulnerability Index (Table 5). The exposure index is based on indicators reflecting the presence of agricultural systems (production units), values (land, harvests), and people (farmers, day laborers, and producer's relatives) who are prone to damage and potential loss due to the hazard. On the other hand, the vulnerability index is based on sensitivity indicators (reflecting the difficulties and problems associated with agricultural production) and adaptive capacity (availability of technical assistance and technology for production).

Table 4. Indicators of the degree of exposure to drought in agricultural systems.

\begin{tabular}{|c|c|c|c|c|}
\hline Indicator & Name & Description & Unit of Measurement & Data Source \\
\hline E1 & Production units & $\begin{array}{l}\text { Number of production units* } \\
\text { including rainfed agriculture as part of } \\
\text { the activities carried out within their } \\
\text { surface areas. }\end{array}$ & Adim. & INEGI (2017) \\
\hline E2 & $\begin{array}{l}\text { Rainfed agricultural } \\
\text { surface }\end{array}$ & $\begin{array}{l}\text { Agricultural area in production units } \\
\text { where the water needed for crop } \\
\text { development comes directly from rain. }\end{array}$ & ha & SIAP (2019) \\
\hline E3 & $\begin{array}{l}\text { Value of agricultural } \\
\text { production }\end{array}$ & $\begin{array}{l}\text { Value obtained from the production of } \\
\text { rainfed crops (beans, maize, wheat, } \\
\text { and sorghum). }\end{array}$ & Thousands of MXN & SIAP (2019) \\
\hline $\mathrm{E} 4$ & Hired personnel & $\begin{array}{l}\text { Number of people hired (day laborers) } \\
\text { for } 6 \text { months or more to carry out } \\
\text { agricultural activities in production } \\
\text { units. }\end{array}$ & Adim. & INEGI (2017) \\
\hline E5 & Producer' relatives & $\begin{array}{l}\text { Number of producer's relatives who } \\
\text { participate in agricultural activity in } \\
\text { production units. }\end{array}$ & Adim. & INEGI (2017) \\
\hline E6 & Producer's dependents & $\begin{array}{l}\text { Total number of people who depend } \\
\text { economically on the producer, } \\
\text { regardless of age and sex. }\end{array}$ & Adim. & INEGI (2017) \\
\hline
\end{tabular}

* A production unit is an economic unit consisting of 1 or more land portions located in the same municipality where at least 1 of them carries out agricultural or forestry activities under the control of the same administration. If the administration includes land located in another municipality, it is considered part of another production unit; that is, there will be as many production units as municipalities occupying their lands. 
Table 5. Indicators of the degree of vulnerability to drought in agricultural systems.

\begin{tabular}{|c|c|c|c|c|c|}
\hline $\begin{array}{c}\text { Component } \\
\text { of Vulnerability }\end{array}$ & Indicator & Name & Description & $\begin{array}{c}\text { Unit of } \\
\text { Measurement }\end{array}$ & Data Source \\
\hline \multirow{5}{*}{ Sensitivity } & S1 & $\begin{array}{l}\text { Difficulty to access } \\
\text { credit and insurance }\end{array}$ & $\begin{array}{l}\text { Percentage of agricultural } \\
\text { production units that have difficulty } \\
\text { accessing credit and insurance to } \\
\text { support their activities. }\end{array}$ & $\%$ & INEGI (2017) \\
\hline & S2 & $\begin{array}{l}\text { Commercialization } \\
\text { problems }\end{array}$ & $\begin{array}{l}\text { Percentage of production units with } \\
\text { agricultural activity that have } \\
\text { problems commercializing their } \\
\text { products (i.e., lack of means of } \\
\text { transportation). }\end{array}$ & $\%$ & INEGI (2017) \\
\hline & S3 & $\begin{array}{l}\text { Unsuitable } \\
\text { organization for } \\
\text { production }\end{array}$ & $\begin{array}{l}\text { Percentage of production units } \\
\text { where agricultural activity is carried } \\
\text { out and IS not part of producers' } \\
\text { organizations to access different } \\
\text { supportS or services. }\end{array}$ & $\%$ & INEGI (2017) \\
\hline & $\mathrm{S} 4$ & $\begin{array}{l}\text { Insufficient } \\
\text { production } \\
\text { infrastructure }\end{array}$ & $\begin{array}{l}\text { Percentage of agricultural } \\
\text { production units lacking sufficient } \\
\text { infrastructure to develop their } \\
\text { economic activities. }\end{array}$ & $\%$ & INEGI (2017) \\
\hline & S5 & $\begin{array}{l}\text { Surface eroded or } \\
\text { impregnated with } \\
\text { saltpeter }\end{array}$ & $\begin{array}{l}\text { Percentage of production units } \\
\text { surface suffering from erosion } \\
\text { problems and saltpeter presence in } \\
\text { their plots that negatively affect } \\
\text { their agricultural productivity. }\end{array}$ & $\%$ & INEGI (2017) \\
\hline \multirow{5}{*}{ Adaptive capacity } & $\mathrm{AC} 1$ & Technical assistance & $\begin{array}{l}\text { Percentage of planted agricultural } \\
\text { surface that was counseled by } \\
\text { qualified technical personnel to } \\
\text { optimally carry out agricultural } \\
\text { tasks (soil preparation, sowing, } \\
\text { fallowing, tracing, fertilization, etc.) }\end{array}$ & $\%$ & SIAP (2019) \\
\hline & $\mathrm{AC} 2$ & $\begin{array}{l}\text { Agricultural } \\
\text { technification }\end{array}$ & $\begin{array}{l}\text { Percentage of sowed surface in } \\
\text { which any type of agricultural } \\
\text { machinery (tractors, harrows, } \\
\text { seeders, graders, threshers, etc.) } \\
\text { were used for soil preparation, } \\
\text { sowing, fruit harvesting, etc. }\end{array}$ & $\%$ & SIAP (2019) \\
\hline & AC3 & Fertilization & $\begin{array}{l}\text { Percentage of the planted area that } \\
\text { includes chemical fertilizers or } \\
\text { agrochemicals in its production } \\
\text { process to improve soil nutrient } \\
\text { content. }\end{array}$ & $\%$ & SIAP (2019) \\
\hline & $\mathrm{AC} 4$ & $\begin{array}{l}\text { Use of improved } \\
\text { seeds }\end{array}$ & $\begin{array}{l}\text { Percentage of agricultural surface } \\
\text { planted with cyclic crops with } \\
\text { variety seeds obtained by highly } \\
\text { selective breeding or selection } \\
\text { process. }\end{array}$ & $\%$ & SIAP (2019) \\
\hline & AC5 & $\begin{array}{l}\text { Phytosanitary } \\
\text { measures }\end{array}$ & $\begin{array}{l}\text { Percentage of the planted } \\
\text { agricultural area receiving plant } \\
\text { health treatment to prevent the } \\
\text { appearance and spread of pests and } \\
\text { diseases that could affect crops. }\end{array}$ & $\%$ & SIAP (2019) \\
\hline
\end{tabular}

Thus, once we selected the indicators and grouped them as indicated in the tables above, we collected the information about them at the municipal level and built a database using an Excel ${ }^{\circledR}$ spreadsheet. Subsequently, we performed a multicollinearity analysis using SPSS ${ }^{\circledR}$ to avoid overrepresenting the selected indicators [33]. Overrepresentation occurs when the variables involved in a model carry redundant data and the information from 1 or more variables is also conveyed by others; that is, there are independent variables that are strongly related to one another [92]. If 2 datasets have values showing a correlation coefficient (r) higher than 0.90 (in the case of a positive correlation) or lower than -0.90 (in the case of a negative correlation), at least 1 of the variables must be eliminated, or otherwise, both are merged and a new indicator is created [93]. In the present study, 
although some indicators showed a high positive correlation (see results in Figures S5-S7 in the Supplementary Materials section), the correlation was not strong enough to discard or merge the indicators, so all the selected indicators were included in the evaluation and normalized.

- Normalization of Indicators

Given that indicators were expressed in different units of measurement $(\%$, ha, MXN, etc.), their values were normalized so that all of them were expressed as dimensionless values between 0 and 1 [20,50]. To carry out this procedure, we used the linear scaling technique (LST) as defined by [94]; linear scaling is a widely used technique for constructing synthetic social and economic indices. Thus, in the case of exposure and sensitivity indicators that have a direct functional relationship with risk, we used the expression

$$
X_{i}=\frac{x_{i}-x_{\min }}{x_{\max }-x_{\min }}
$$

In the case of adaptive capacity indicators, whose functional relationship with risk is inverse, we used the following formula:

$$
X_{i}=\frac{x_{\max }-x_{i}}{x_{\max }-x_{\min }}
$$

In both equations: $X_{i}$ is the normalized value of variable $x_{i}$ and $x_{\min }$ and $x_{\max }$ are the minimum and maximum values of dataset $x_{i}$, respectively.

- Weighting of indicators

After obtaining normalized indicator values, we calculated their weights using the method proposed by [95], which uses the following expression:

$$
W_{i}=\frac{1}{\left(\sigma_{i}\right)\left(\sum_{i=1}^{n} \frac{1}{\sigma_{i}}\right)}
$$

where $W_{i}$ is the normalized indicator weight $i, \sigma_{i}$ is the standard deviation of the set of values for indicator $i$, and $n$ is the number of selected indicators.

This weighting method prevents abnormally large variations in 1 or many indicators from overshadowing the contribution of the rest of the indicators [20,50].

- Calculation of exposure and vulnerability indices

The following formula is used to calculate drought exposure indices (DEI):

$$
D E I=\sum_{i=1}^{n} X_{i} W_{i}
$$

where $X_{i}$ is the normalized value of indicator $i, W_{i}$ is the weight of normalized indicator $i$, and $n$ is the number of drought exposure indicators.

To calculate vulnerability indices, we first determined their components, i.e., sensitivity index (SI) and adaptive capacity index (ACI) using the following expression:

$$
S I=A C I=\sum_{i=1}^{m} X_{i} W_{i}
$$

where $X_{i}$ is the normalized value of indicator $i, W_{i}$ is the weight of normalized indicator $i$, and $m$ is the number of indicators associated with the respective component (sensitivity or adaptive capacity).

Subsequently, we calculated drought vulnerability indices (DVI) by integrating the 2 previous indices and assuming a weight $W_{i}$ of 12 for each of them (Equation (17). In this case, we adjusted the $A C I$ index by inverting its sign (according to the functional 
relationship expressed in Equation (2) to indicate that the higher the adaptive capacity, the lower the vulnerability; for this reason, we subtracted this index from that in Equation (17):

$$
D V I=\frac{S I+(1-A C I)}{2}
$$

- Fitting of exposure and vulnerability indices to a probability distribution

To classify the exposure and vulnerability indices divided into 5 equally-sized categories, we tested different PDFs to fit the data using the EasyFit ${ }^{\circledR}$ software and found that, similarly to hazard indices, the General Extreme Value distribution fits well to the sample values in both cases (see Figures S2 and S3 in the Supplementary Materials section).

Subsequently, we multiplied the values of the standardized indices by 100 to express them as percentages and then grouped them into 5 percentile categories of equal size (similar to the drought hazard indices), as shown in Table 6. This classification into 5 categories is taken from our previous work $[20,50]$ because it has the advantage that it makes it possible to easily display and distinguish the different degrees of exposure and vulnerability that municipalities have when they are represented on a map.

- Mapping of exposure and vulnerability indices

Table 6. Categories to classify the degree of exposure and vulnerability to drought.

\begin{tabular}{cc}
\hline Degree of Exposure or Degree of Vulnerability & Value of Percentile $^{*}$ \\
\hline Very low & $0<I_{i} \leq 20$ \\
Low & $20<I_{i} \leq 40$ \\
Moderate & $40<I_{i} \leq 60$ \\
High & $60<I_{i} \leq 80$ \\
Very high & $80<I_{i} \leq 100$ \\
\hline
\end{tabular}

* Where $I_{i}$ refers to the exposure index or the vulnerability index accordingly.

We created maps to graphically represent exposure and vulnerability to agricultural drought using a similar procedure as in the case of the drought hazard maps using the ArcGis ${ }^{\circledR}$ software and the National Geostatistic Framework as a base map [68].

\subsubsection{Determination of Agricultural Drought Risk Indices}

Once the hazard, exposure, and vulnerability to agricultural drought indices were calculated, we determined drought risk indices (DRI) at the municipal level based on the additive combination of the 3 previous indicators, which were then weighted equitably assuming a weight $W_{i}$ of 13 for each of them:

$$
D R I=\frac{D H I+D E I+D V I}{3}
$$

Subsequently, we adjusted risk indices to a probability distribution using EasyFit ${ }^{\circledR}$ software and found that similar to the hazard, exposure, and vulnerability to drought indices, the GEV distribution fit well with risk indices (see Figure S4 in the Supplementary Materials); therefore, we used this probability distribution and classified the standardized indices. Thus, we grouped the drought risk indices into 5 categories (analogous to the hazard, exposure, and vulnerability indices), each of them representing a 20-percent range, and classified them as follows: very low (0-20), low (21-40), medium (41-60), high (61-80), and very high (81-100). Based on this classification, we proposed that the criteria for risk acceptability would be as follows: if the level of risk was low or very low, it was an acceptable risk; if the level of risk was moderate, it was improvable; and if the level of risk was high or very high, it was not acceptable and measures should be put in practice to reduce it. Finally, we developed the agricultural drought risk map at the municipal level using the ArcGis ${ }^{\circledR}$ software, using the National Geostatistical Framework as a base map [68]. 


\section{Results}

\subsection{Agricultural Drought Hazard}

\subsubsection{Areas Affected by Agricultural Drought}

Figure 7 shows annual maps of Zacatecas according to mean annual VHI values (1985-2019); these maps show the intensity of water stress in the agricultural areas where the crops of interest are grown for each year in the series. The maps reveal five episodes of severe drought: 1989, 1995-1997, 1999-2001, 2005, and 2011-2012. The last event has been the most profusely documented concerning the repercussions of the most severe drought in the country's central and northern states since 1941; the event took place in 2011-2012, affecting 1,213 municipalities in 19 states [12,13]. The maps also show that agriculture is in constant hazard of drought in the state of Zacatecas; the crops of interest present a water stress trend $(\mathrm{M}-\mathrm{VHI}<0.35)$ in at least $50 \%$ of the analyzed years.

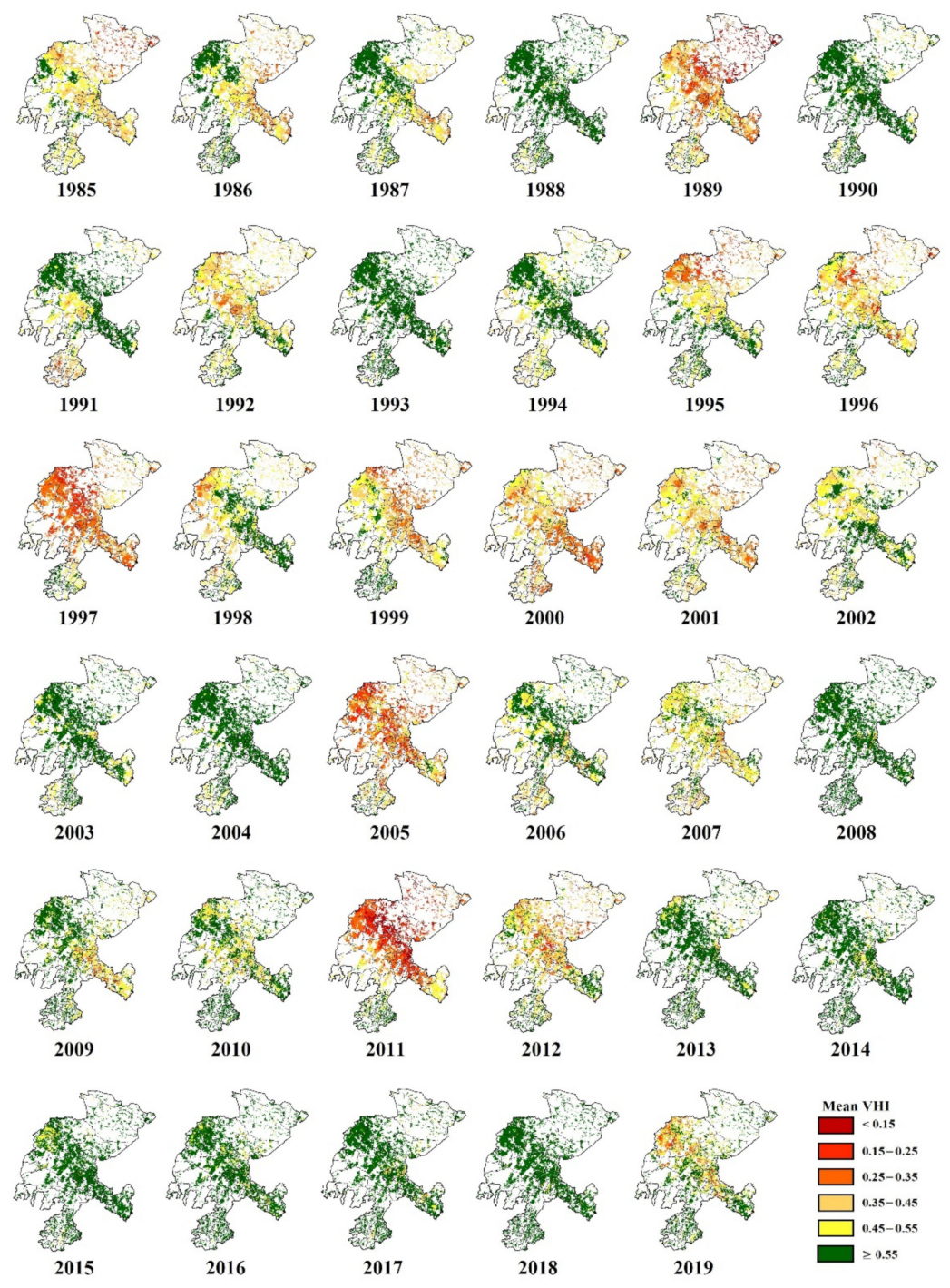

Figure 7. Mean annual VHI values for selected crops in Zacatecas (1985-2019).

Similarly, Figure 8 allows for quantitative analysis of the percentage of agricultural surface affected by drought (ASI) at the municipal level for the same analysis period (1985-2019). Considering the years when vegetation health was poorest $(1989,1995-1997$, 1999-2001, 2005, and 2011-2012), the ASI index showed that, in the worst years (1997, 2005, and 2011), more than $50 \%$ of the agricultural areas of most municipalities in the state of Zacatecas were affected by drought. In at least $40 \%$ of the analyzed years, at least one municipality presented a percentage of agricultural surface affected by drought between 
30 and $50 \%$. In general, the studied area is characterized by frequent and, in some cases, severe drought intensity in the central and northern parts of the state, where the main agricultural areas are located.
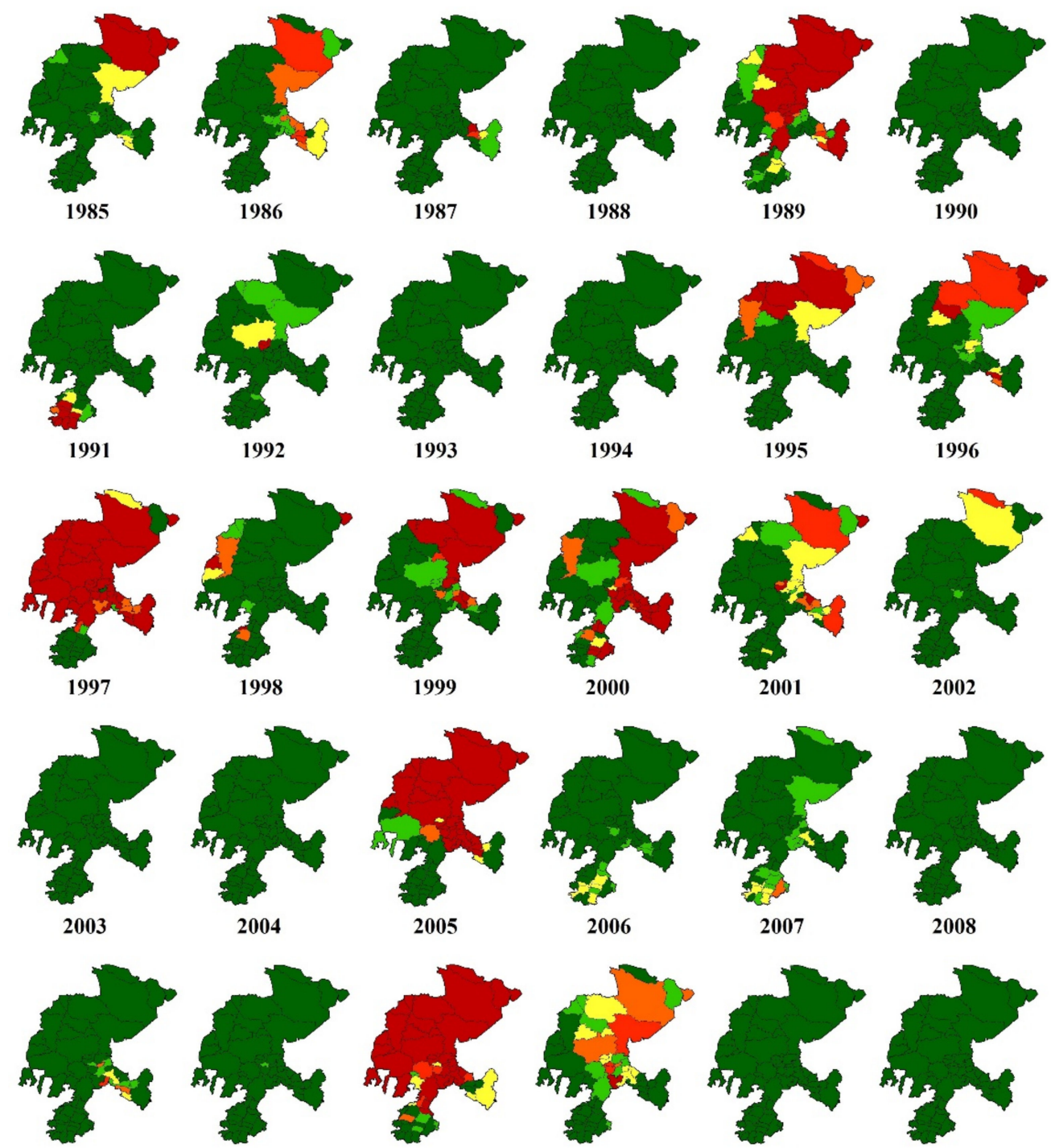

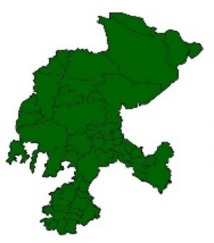

2015

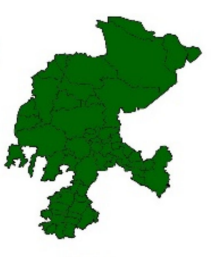

2016

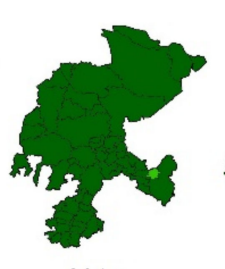

2017

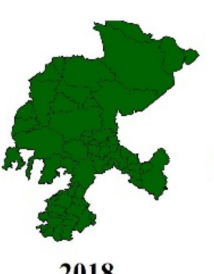

2018

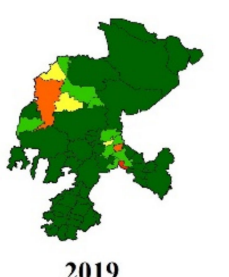

2014

Figure 8. Evolution of average percentage of area affected by drought (ASI) in Zacatecas (1985-2019).

These results are in general agreement with those obtained by other studies analyzing drought in the state of Zacatecas using different meteorological drought indices, among them the Standardized Precipitation Index (SPI) $[42,58,96]$, the Reconnaissance Drought Index (RDI) [42,58], and the Standardized Precipitation-Evapotranspiration Index (SPEI) [42]. These studies found that the most severe droughts occurred during the study period between 2005 and 2011 [58,96], and they also identified the most important dry periods, such as 1995-1997, 1999-2001, and 2011-2012 [41,42]. 
The results of our investigation are also largely in line with data on agricultural surfaces affected by climatic and hydro-meteorological phenomena (drought, frost, snow, hailstorms, etc.) in the state of Zacatecas, which are reported annually by SIAP [67] (Figure 9). This figure shows the evolution of the affected area and the damage caused by this type of phenomenon from 1985 to 2019 for the rainfed crops analyzed in the present study (bean, maize, sorghum, and wheat). In some years, the impact on crops could be caused by one or more climatic phenomena, but unfortunately, the statistics reported by SIAP fail to differentiate the damages attributed to each phenomenon; however, in Zacatecas, the main climatic disaster is known to be drought [97,98]. Thus, Figure 9 shows the years in which severe agricultural drought occurred in most of the state $(1989,1997$, 2005, and 2011) in red (Figure 8); the figure shows a trend toward an increase in both affected area and economic losses as a result of this phenomenon. As can be observed, a severe drought event occurs approximately every 8 years. In the last 2 years of severe drought (2005 and 2011), the affected area was more than 350 thousand hectares, and the damage caused was more than 1 billion MXN (approximately 50 million USD); 2011 saw the most considerable economic losses throughout the study period: more than 1.2 billion MXN (approximately 60 million USD).

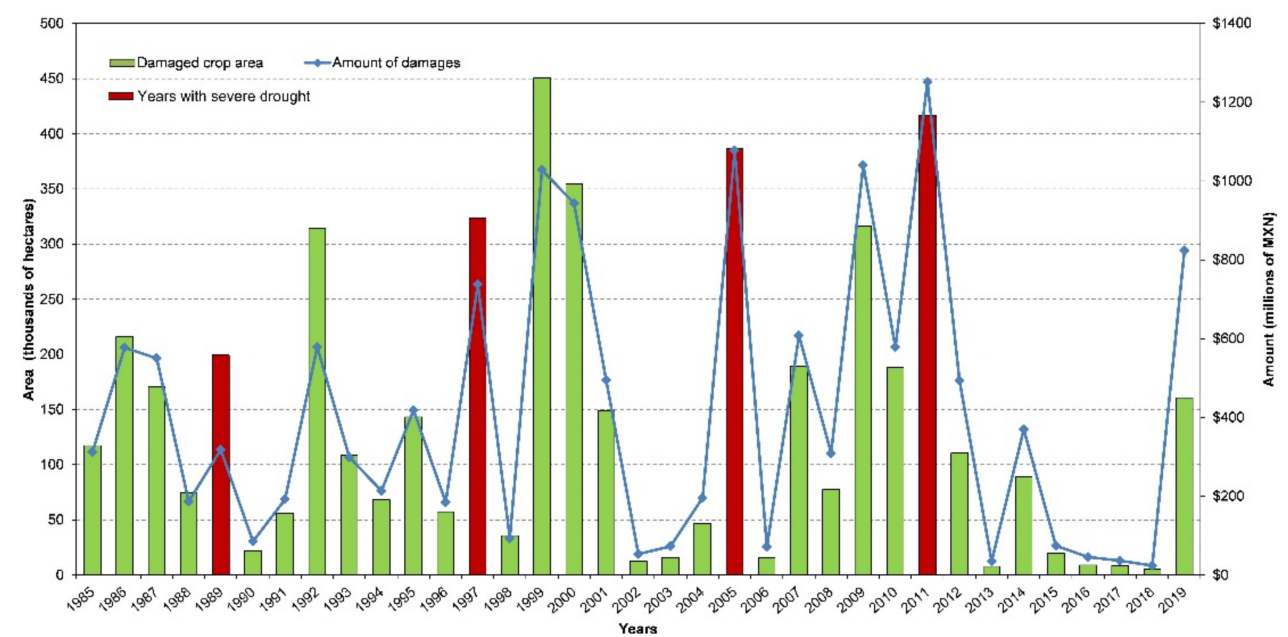

Figure 9. Affected agricultural surface and amount of annual damage to rainfed crops in Zacatecas (1985-2019). Source: prepared by the author using information from SIAP [67].

According to the National Center for Disaster Prevention (CENAPRED), more than $40 \%$ of rainfed agricultural land in the spring-summer cycle was lost in the state of Zacatecas in 2005, specifically, maize, bean, and oatmeal, and thousands of livestock were affected because the pastures were not fully developed and the drinking troughs were dry [99]. Similarly, CENAPRED reported that drought affected more than 267 thousand hectares in 2011 and that more than 160 thousand livestock were lost, equivalent to 1.7 billion MXN (approximately 88 million USD) [14]. Although the damage was probably more intense, 42 of the 58 municipalities in the state were officially declared as disaster areas due to severe drought from May 1 to November 30, 2011 [100], which allowed them access to the economic resources of the Natural Fund for Disasters (FONDEN). Moreover, the drought period lasted until 2012 (although the damaged area decreased considerably in comparison with the previous year, as can be observed in Figures 8 and 9), which resulted in a new declaration of natural disaster due to atypical, unpredictable, and non-recurrent droughts from June 1 to August 31, 2011, for the vast majority of the state's municipalities [101].

\subsubsection{Degree of Drought Hazard by Municipality}

Figure 10 shows the agricultural drought hazard map at the municipal level in Zacatecas obtained from the DHI values (proposed in this study), which was calculated using the historical values of the ASI index. As can be observed in this map, the municipali- 
ties with the highest degrees of hazard are located in the north and center of the state, precisely in the arid and semiarid regions, which are regularly affected by droughts of different intensities [58]. In order of size, municipalities with a very high degree of drought hazard are Mazapil, Villa de Cos, Gral. Fco. R. Murguía, and Melchor Ocampo, among others. However, although the largest municipality in the state is Mazapil $(16.1 \%$ of the state surface), only $1.3 \%$ of its agricultural surface is rainfed, and therefore, the effects of drought in this municipality have a minor impact on the state as a whole. On the other hand, the seven municipalities with the largest agricultural surface (Sombrerete, Fresnillo, Río Grande, Villa de Cos, Miguel Auza, General Fco. R. Murgía, and Sain Alto, which account for $50.3 \%$ of the sown area per year) have high and very high degrees of drought hazard. Therefore, given that practically half of the state's agricultural activity occurs in these municipalities, if they are affected by drought, the negative impacts on regional and national economies are severe since it affects not only agriculture but also the livestock and services sectors [97].

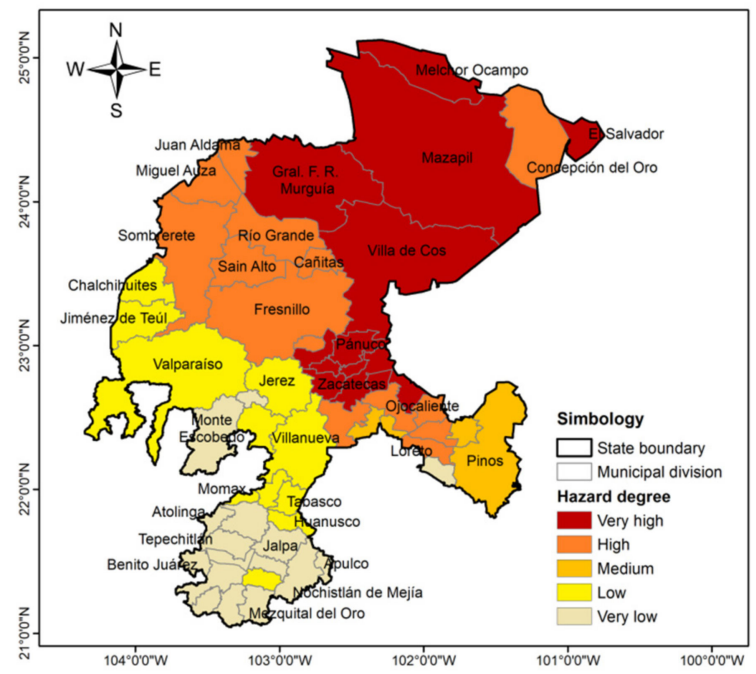

Figure 10. Agricultural drought hazard map.

This distribution of agricultural drought hazard is in marked agreement with the distribution of total annual precipitation in the state of Zacatecas [102,103]. Municipalities with a very high degree of agricultural drought hazard are located in the Semi-desert region and have the lowest annual precipitation, ranging from 300 to $400 \mathrm{~mm}$; municipalities with a high degree of drought hazard are located in the Highlands region and have annual average precipitation of $400-500 \mathrm{~mm}$; municipalities with medium and low degrees of drought hazard are located in the Mountains region, and their annual precipitation ranges from 500 to $700 \mathrm{~mm}$; municipalities with a very low degree of drought hazard are located in the Canyons region, and their precipitation is over $700 \mathrm{~mm}$ per year. In other words, the degree of agricultural drought hazard is inversely related to the amount of rainfall in each region, which is greatly influenced by relief. Thus, relief and rain patterns define the production activities carried out by the inhabitants of each region. As expected, the municipalities with the highest agricultural potential are located in the Highlands region, characterized by extensive grasslands and low-slope plains [104] favorable for the production of beans and forage crops such as corn and oats, as well as horticultural species such as pepper, onion, chili, and garlic. Goat-rearing is common in the Semi-desert region to produce meat and milk; the Mountains region is characterized by forestry activities; and the main activities in the Canyons region are the production of calves, guava, tequila agave, and a great variety of vegetables and flowers [102]. 


\subsection{Exposure to Agricultural Drought}

Drought exposure is defined as the presence of people, property, livelihood forms, and systems that are prone to potential damage and loss due to the hazard [62]. In this case, exposure includes rainfed cultivated areas, agricultural production units, and farmers themselves, as well as their dependents and other people working in the agricultural sector who are at risk of losing their jobs, food sources, and economic income. Figure 11 presents a map of agricultural drought exposure at the municipal level for the state of Zacatecas. This map shows that most of the municipalities in the center region (the Highlands region) have a very high degree of exposure to agricultural drought since this is where the main rainfed maize- and bean- producing municipalities are located (Fresnillo, Sombrerete, Río Grande, Sain Alto, General Fco. R. Murgía, and Villa de Cos, among others). The southeast municipality of Pinos is also important for agriculture in the state.

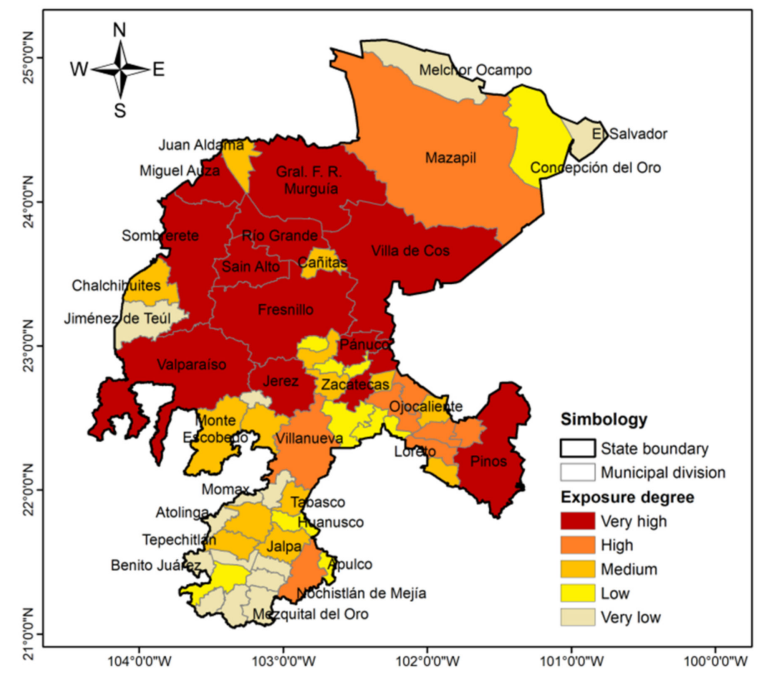

Figure 11. Exposure to agricultural drought map.

Table 7 presents the distribution of the number of municipalities, rainfed agricultural surface, production units, and people who depend on agriculture by the degree of agricultural drought exposure. The table shows that $34.5 \%$ of the state's municipalities have high and very high degrees of drought exposure and account for $78.6 \%$ of rainfed agricultural land and $75.6 \%$ of production units; $75.5 \%$ of people who depend on agricultural activity work, including day laborers, farmers, and their families live in these municipalities. Therefore, given that practically three-quarters of the population who depend on agriculture lives in these municipalities, the presence of drought in these regions has severe socioeconomic impacts throughout the state. This is because producers of staple crops such as maize and beans often use family labor to carry out agricultural work and, as a complement, hire personnel over the agricultural cycle. Most hired laborers come from communities in the same municipality or neighboring ones and form crews to reduce transportation costs. An evident shortage of day laborers has been identified in certain municipalities, especially for the harvest, since they prefer to provide their services to producers who grow more than 20 hectares to guarantee their occupation for the longest time possible [105]. 
Table 7. Distribution of the number of municipalities, rainfed agricultural surface, production units, and people who depend on agriculture by the degree of agricultural drought exposure.

\begin{tabular}{|c|c|c|c|c|c|c|c|c|}
\hline \multirow{2}{*}{$\begin{array}{l}\text { Degree of } \\
\text { Exposure }\end{array}$} & \multicolumn{2}{|c|}{ Municipalities } & \multicolumn{2}{|c|}{$\begin{array}{c}\text { Rainfed Agricultural } \\
\text { Area }\end{array}$} & \multicolumn{2}{|c|}{ Production Units } & \multicolumn{2}{|c|}{$\begin{array}{c}\text { People Who Depend on } \\
\text { Agriculture * }\end{array}$} \\
\hline & No. & $\%$ & ha & $\%$ & No. & $\%$ & No. & $\%$ \\
\hline Very high & 12 & 20.7 & 720,729 & 68.4 & 78,926 & 59.9 & 336,528 & 59.7 \\
\hline High & 8 & 13.8 & 107,245 & 10.2 & 20,704 & 15.7 & 88,901 & 15.8 \\
\hline Medium & 14 & 24.1 & 138,365 & 13.1 & 17,809 & 13.5 & 81,172 & 14.4 \\
\hline Low & 10 & 17.2 & 57,500 & 5.5 & 7,885 & 6.0 & 32,479 & 5.8 \\
\hline Very low & 14 & 24.1 & 29,969 & 2.8 & 6,373 & 4.8 & 24,648 & 4.4 \\
\hline Total & 58 & 100.0 & $1,053,807$ & 100.0 & 131,697 & 100.0 & 563,728 & 100.0 \\
\hline
\end{tabular}

* Includes farmers, hired day laborers, and family members who depend economically on the farmers.

In the main agricultural municipalities, producers used to own an average of 40 hectares. Over the past decades, the surface area per farmer has decreased because the land is being sold or inherited (quite common in the region). The consequences of reducing arable land per producer are: (1) Unemployment because large producers often use technological solutions and employ fewer day laborers; (2) Productivity becoming increasingly more difficult to achieve because small producers cannot afford technification [106]. Therefore, small producers are more likely to lose their crops and economic income due to drought.

\subsection{Vulnerability to Agricultural Drought}

Vulnerability to agricultural drought describes, on the one hand, how susceptible rainfed agricultural production systems are to the impacts of drought hazard, and on the other hand, what skills or resources (adaptive capacities) the systems have to cope with the impact. Figure 12 presents a map of the degree of vulnerability to agricultural drought in Zacatecas. It shows that highly vulnerable municipalities are located mainly in the center, many of them characterized by their large size, especially in the case of Sombrerete, Río Grande, Fresnillo, and Villa de Cos. There are other large municipalities with a high degree of vulnerability throughout the state, such as Mazapil, Gral. Fco. R. Murgía, Juan Aldama, and Miguel Auza in the north; Sain Alto and Valparaíso in the center, and the municipality of Pinos in the southeast, among others.

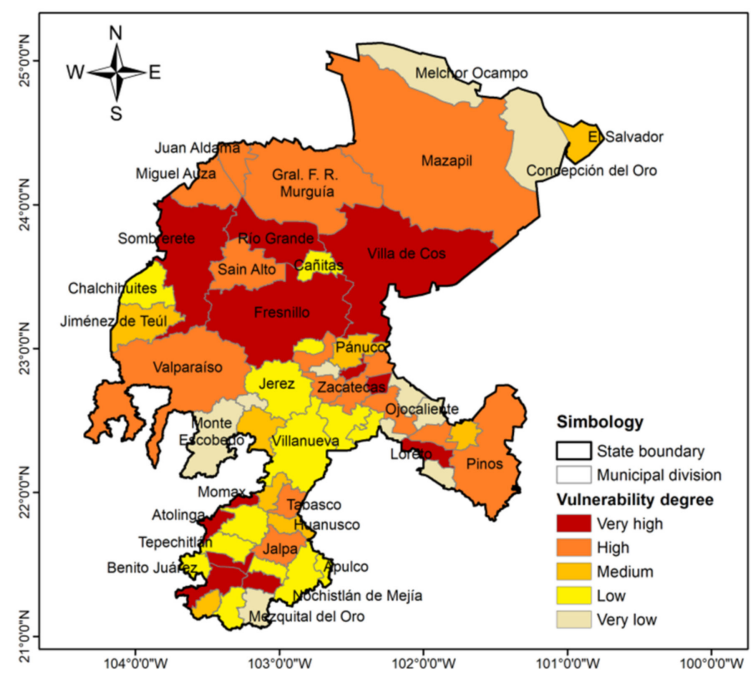

Figure 12. Vulnerability to agricultural drought map.

Table 8 presents a summary of sensitivity indicators in agricultural production systems according to their degree of vulnerability to drought. From this table, it can be deduced that, in sum, $45.68 \%$ of production units with high and very high degrees of vulnerability have difficulty accessing loans and insurance; $37.12 \%$ have problems commercializing their 
products; $27.43 \%$ lack sufficient production infrastructure, and $18.22 \%$ are unsuitable for production. These four characteristics are the main determinants of their high degree of vulnerability. Production units where the surface is eroded and rich in saltpeter represent a minimum percentage (less than $1.00 \%$ ); this percentage is not significant for the entire state of Zacatecas.

Table 8. Average value of sensitivity indicators according to the degree of vulnerability to agricultural drought.

\begin{tabular}{cccccc}
\hline $\begin{array}{c}\text { Degree of } \\
\text { Vulnerability }\end{array}$ & $\begin{array}{c}\text { Difficulty of } \\
\text { Access to Credit } \\
\text { and Insurance * }\end{array}$ & $\begin{array}{c}\text { Problems in } \\
\text { Commercialization * }\end{array}$ & $\begin{array}{c}\text { Unsuitable } \\
\text { Organization for } \\
\text { Production * }\end{array}$ & $\begin{array}{c}\text { Insufficient } \\
\text { Production } \\
\text { Infrastructure * }\end{array}$ & $\begin{array}{c}\text { Surface Eroded or } \\
\text { Impregnated with } \\
\text { Saltpeter * }\end{array}$ \\
\hline Very high & 25.99 & 21.40 & 11.76 & 17.73 & 0.28 \\
High & 19.69 & 15.72 & 6.46 & 9.70 & 0.05 \\
Medium & 18.55 & 5.40 & 5.28 & 5.91 & 0.29 \\
Low & 10.56 & 6.81 & 0.17 & 2.04 & 0.02 \\
Very low & 6.23 & 3.42 & $\mathbf{5 . 4 5}$ & $\mathbf{8 . 4 6}$ \\
\hline Average & $\mathbf{1 6 . 2 0}$ & $\mathbf{1 0 . 5 5}$ & $\mathbf{5 . 1 3}$ & \\
\hline
\end{tabular}

* In all cases, the value represents the average percentage of production units presenting the specified problem.

Table 9 presents the strengths (adaptive capacities) of agricultural production systems according to their degree of vulnerability to drought. This table shows that, regardless of the degree of vulnerability, the adaptive capacities of agricultural production systems in the state of Zacatecas are very low, since, in the vast majority of cases, less than $2.00 \%$ of the agricultural surface used technical assistance, agricultural machinery, and other technologies (fertilizers, improved seeds, and plant health treatments) to produce crops.

Table 9. Average value of adaptive capacity indicators according to the degree of vulnerability to agricultural drought.

\begin{tabular}{cccccc}
\hline $\begin{array}{c}\text { Degree of } \\
\text { Vulnerability }\end{array}$ & $\begin{array}{c}\text { Technical } \\
\text { Assistance }\end{array}$ & $\begin{array}{c}\text { Agricultural } \\
\text { Mechanization * }\end{array}$ & Fertilization * & $\begin{array}{c}\text { Use of Improved } \\
\text { Seeds * }\end{array}$ & $\begin{array}{c}\text { Phytosanitary } \\
\text { Measures * }\end{array}$ \\
\hline Very high & 3.60 & 2.63 & 4.58 & 0.07 & 6.81 \\
High & 2.47 & 2.46 & 2.09 & 0.01 & 0.74 \\
Medium & 0.68 & 1.15 & 0.33 & 0.02 & 1.46 \\
Low & 0.77 & 1.17 & 0.68 & 0.01 & 1.05 \\
Very low & 0.66 & 0.61 & 0.24 & 0.01 & 1.36 \\
\hline Average & $\mathbf{1 . 7 3}$ & $\mathbf{1 . 6 8}$ & $\mathbf{1 . 7 0}$ & $\mathbf{0 . 0 2}$ & $\mathbf{2 . 2 8}$ \\
\hline
\end{tabular}

* In all cases, the value represents the average percentage of planted agricultural area in which the specified feature was used.

Apparently, production units with very high vulnerability use more technology than the rest (since they have the highest percentages of adaptive capacity indicators), which may seem paradoxical. However, the reality is that these production systems are located in the main agricultural municipalities in the state and, consequently, are technically more advanced than the rest; nevertheless, these municipalities are equally vulnerable because, as described above, their weaknesses far outweigh their strengths.

In the main agricultural municipalities, large producers have successfully adapted to technological change and trade liberalization derived from the North American Free Trade Agreement (NAFTA), signed in 1992 between Mexico, the United States of America, and Canada. Since 1993, when the agreement was signed, Mexican farmers (especially low-income farmers whose production is mostly used for self-consumption) have received annual economic support through the Direct Agricultural Support Program (PROCAMPO) as a compensatory aid before the commercial opening of NAFTA, which entailed a competitive disadvantage for national producers given the high subsidies granted to their counterparts in the partner countries. However, despite the government's intentions, resources were not invested in inputs or agricultural machinery because many farmers used them to help their families survive or to pay debt [106]; the technological level of 
agricultural production is still very low and, therefore, highly vulnerable to climate events such as drought and other extreme phenomena.

\subsection{Agricultural Drought Risk}

The integration of municipal indices of hazard, exposure, and vulnerability to agricultural drought resulted in risk indices whose spatial distribution in the state of Zacatecas can be appreciated in Figure 13. This map is congruent and consistent with the previous maps; municipalities at very high drought risk (Sombrerete, Fresnillo, Río Grande, General Fco. R. Murgía, Villa de Cos, and Miguel Auza) are mainly located in the center and north of the state, and they are the most important to agriculture.

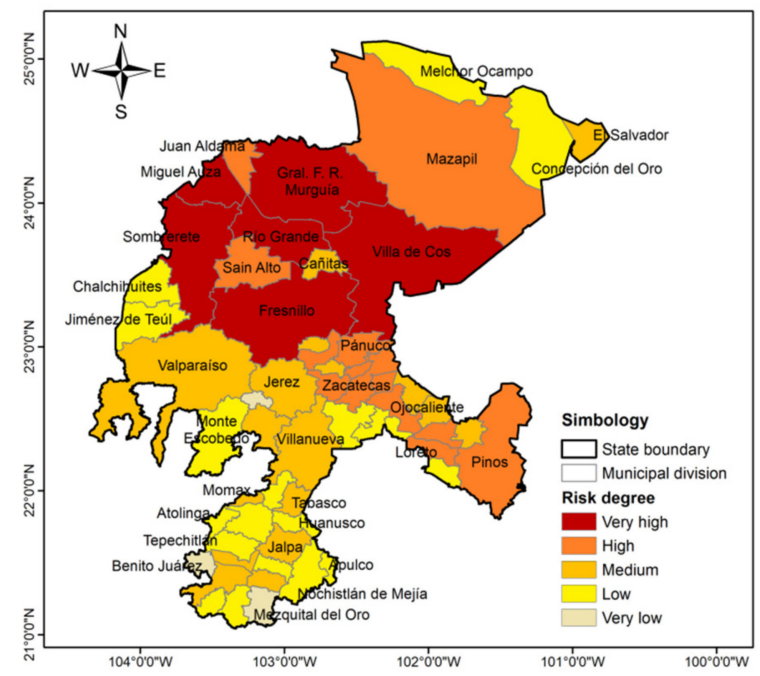

Figure 13. Agricultural drought risk map.

These results are in line with records of agricultural surface affected by weather phenomena (droughts, frosts, hailstorms, etc.), published annually by SIAP [67] and available at the municipal level from 2003 to 2019. Figure 14 shows the total affected area surface and the total amount of damage caused by these phenomena over the period to the rainfed crops considered in the present study (beans, maize, wheat, and sorghum). In some years and municipalities, the impact on crops could have been due to one or more climatological phenomena, but the SIAP statistics fail to differentiate the damage caused by each phenomenon. However, the municipalities that the present study found to be at a very high risk of agricultural drought are shown in red in Figure 14; these municipalities are also the ones reporting the highest economic losses and the largest affected areas due to climate-related phenomena. The following were the most affected municipalities arranged from the least to the most affected: Fresnillo, Villa de Cos, Gral. Fco. R. Murguía, Río Grande, Sombrerete, and Miguel Auza. Similarly, the same figure shows that the affected areas in these municipalities during the 2003-2019 period were larger than 80 thousand hectares in each (more than 160 thousand hectares in Fresnillo), and economic losses in all cases were higher than 250 million MXN (approximately 12.5 million USD) and higher than 500 million MXN (approximately 25.0 million USD) in the municipality of Fresnillo. 


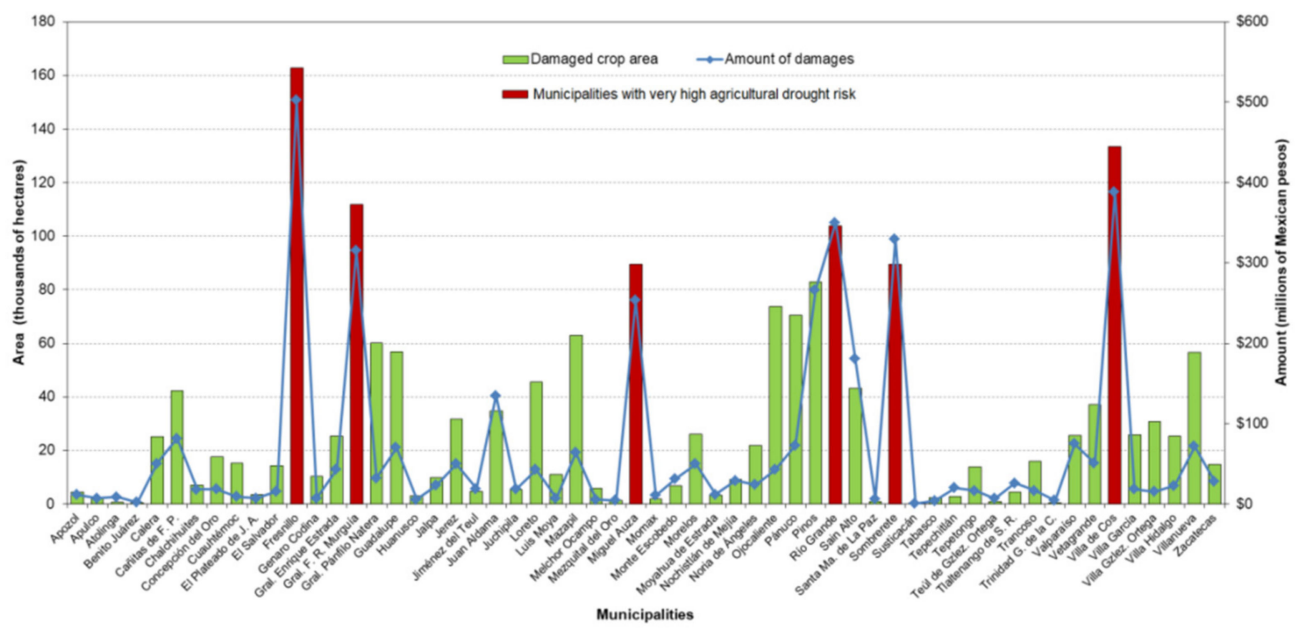

Figure 14. Sum total of damaged agricultural area and the total amount of damage per municipality for rainfed crops in Zacatecas from 2003 to 2019.

Table 10 presents the distribution of the number of municipalities, rainfed agricultural surface area, production units, and people who depend on agriculture by their degree of agricultural drought risk. The table shows that $32.7 \%$ of the state's municipalities have a high and very high degree of drought risk; $75.8 \%$ of the state's rainfed agricultural land and $63.6 \%$ of its production units are located in these municipalities, and $67.4 \%$ of the people who depend on agricultural work, including day laborers, farmers, and their dependents live there. Therefore, the state's agricultural activity is at risk of facing the adverse effects of drought. Livestock grazing is another economic activity at risk because drought decreases the production of pasture, and water becomes scarce at livestock troughs [97].

Table 10. Distribution of the number of municipalities, rainfed agricultural surface, production units, and people who depend on agriculture by their degree of agricultural drought risk.

\begin{tabular}{|c|c|c|c|c|c|c|c|c|}
\hline \multirow{2}{*}{$\begin{array}{c}\text { Risk } \\
\text { Degree }\end{array}$} & \multicolumn{2}{|c|}{ Municipalities } & \multicolumn{2}{|c|}{ Rainfed Agricultural Area } & \multicolumn{2}{|c|}{ Production Units } & \multicolumn{2}{|c|}{$\begin{array}{c}\text { People Who Depend on } \\
\text { Agriculture * }\end{array}$} \\
\hline & No. & $\%$ & ha & $\%$ & No. & $\%$ & No. & $\%$ \\
\hline Very high & 6 & 10.3 & 497,925 & 47.3 & 38,030 & 28.9 & 169,496 & 30.1 \\
\hline High & 13 & 22.4 & 300,763 & 28.5 & 45,702 & 34.7 & 210,542 & 37.3 \\
\hline Medium & 17 & 29.3 & 164,954 & 15.7 & 28,742 & 21.8 & 106,571 & 18.9 \\
\hline Low & 19 & 32.8 & 84,518 & 8.0 & 18,138 & 13.8 & 71,951 & 12.8 \\
\hline Very low & 3 & 5.2 & 5,648 & 0.5 & 1,085 & 0.8 & 5,168 & 0.9 \\
\hline Total & 58 & 100.0 & $1,053,807$ & 100.0 & 131,697 & 100.0 & 563,728 & 100.0 \\
\hline
\end{tabular}

The high risk of agricultural drought in the most important bean-producing municipalities of Zacatecas is especially important for regional and state food security; in severe cases, it can have national repercussions because the state is Mexico's main bean producer [67]. This legume is essential in the national diet and is the primary protein source for a large part of the population; it cannot be replaced by a similar low-priced food [107]. Therefore, any effect on the state's bean production will have adverse effects beyond the local or regional scale. When bean production decreases as a result of drought, legume prices tend to increase at the national level and imports increase, especially from the United States of America [107]. 


\section{Discussion}

The results of this study should be discussed within the broader context of natural climate variability, global climate change, national vulnerability to drought, and public policies implemented by Mexico to reduce vulnerability.

Concerning natural climate variability, it is important to highlight that the geographical location of the state of Zacatecas makes it particularly prone to drought with some frequency since it is located between the interior basins of the center-north region (i.e., the Mexican Plateau) characterized by low precipitation and general aridity due to its location with respect to the subtropical high-pressure zone and the general orientation of its geographical barriers [96]. Other precipitation phenomena, such as El Niño-Southern Oscillation (ENSO) and the Pacific Decadal Oscillation (PDO) also influence precipitation: they tend to produce above-average rainfall in Zacatecas in their positive (warm) phases $[103,108]$. However, the effects of El Niño are not always associated with higher rainfall, since, for example, when this phenomenon occurred in 1997, its effects on national agriculture (including Zacatecas) were low rainfall and crop losses of up to $50 \%$, mostly rainfed maize and bean [109]. Thus, although some relationships between El Niño, La Niña (ENSO's cold phase), and Mexico's precipitation variability have been found, this information is insufficient to predict the magnitude and severity of a drought event, much less to determine its potential effects on different economic activities such as agriculture [110]. This is because the intensity of the El Niño phenomenon has been observed to be unrelated to the severity of drought in Mexico and other parts of the world. [111]. An example of this lack of an association is the 2011-2012 drought that affected most of the national territory and could not be related to the El Niño phenomenon because the cold phase of ENSO (La Niña) was taking place during those years [110].

In fact, climate variability in the state of Zacatecas has increased over the past years. Recent research shows an increase in both dry and wet periods, i.e., increasing extreme weather over time [96]. According to a study by [41], from 1950 to 2014, extreme severe meteorological droughts occur in the state of Zacatecas around every 10 years. In the present study, severe agricultural droughts were observed to occur every 8 years from 1935 to 2019, increasing in frequency in recent decades. According to research by [42], total annual precipitation as wet days decreased by $6.20 \mathrm{~mm}$ per decade in the state from 1961 to 2014. This reduction was mainly concentrated in the center and south of the state and was associated with a decrease in autumn and summer rain; the number of consecutive dry days (annual regional average) tended to increase, with $58.6 \%$ being statistically significant, especially in central and southern Zacatecas. In this regard, in a study by [102], trends estimated by the SPI index were found to be predominantly negative toward the end of the study period (1964-2014), which indicates lower-than-mean precipitation throughout the state. Other studies have found no decrease in total precipitation in the state, but rainy days are most certainly less frequent and more intense [108]. Temperature changes have also been observed: maximum temperatures have increased significantly, and minimum temperatures have decreased, resulting in an amplification of thermal oscillation [108]. These temperature changes (especially those associated with higher maximum temperatures) are consistent with nationwide $[15,112]$ and global $[62,113]$ observations, an indication that local and regional trends reflect climate change taking place at the planetary scale [62]. In this context, the changes in precipitation and temperature patterns in Zacatecas represent a risk of adverse conditions for agricultural production because these changes affect the duration of the crop's phenological cycle, increase potential evapotranspiration, and consequently, plants have higher requirements to meet their demands, which can have a negative impact on rainfed crop production [114], hence the need for management practices and systems capable of maintaining agricultural production and avoiding food security problems [115].

However, as described in the present article, the socioeconomic and environmental conditions of agricultural production systems, which determine the degree of exposure and vulnerability to agricultural drought in the state, are quite unfavorable. However, these conditions are not unique to the state of Zacatecas: high economic, social, and environmen- 
tal vulnerability indices prevail in other parts of the country. It is estimated that $24.7 \%$ of Mexican municipalities are highly or very highly vulnerable to drought; these municipalities represent $52.2 \%$ of the national territory and are home to 43.7 million people, $38.9 \%$ of the national population [20]. The socioeconomic and environmental characteristics of these municipalities make them especially susceptible, for example, poverty, marginalization, and social backwardness; their agricultural and stockbreeding activities are sensitive and exposed to climate variations due to the lack of an adequate infrastructure; they suffer from severe deterioration of natural resources due to deforestation, soil degradation, and aquifer overexploitation, among others [20]. Vulnerability to drought is inversely related to the degree of economic and social development in the affected areas, whereas drought is rarely a serious threat to the more-developed regions because they have the economic and structural means to cope with the phenomenon; in the less-developed areas, drought is frequently followed by hunger, poverty, migration, and reduced well-being and quality of life, situations against which local inhabitants have very few elements to cope $[20,116]$. The technological level of a region or country, as well as its organizational, institutional, and social profiles, are key elements in vulnerability to drought. A clear example of these differences in vulnerability can be observed when comparing Mexican and American farmers living near the border between their countries: they share similar physical and biological conditions compared to their different social, political, economic, and historical backgrounds [116,117]. The former are clearly more vulnerable than the latter. In Mexico, water availability is a decisive factor for populations and small communities to be abandoned by an economically active population who seek opportunities elsewhere, either in large cities or in the neighboring country to the north. These circumstances often exacerbate the social effects of the phenomenon; they create "ghost towns" where only women, children, and old people remain, living off the meager products of their lands and the resources sent by their young who have migrated and are irrefutable proof of the scope and impact of drought [118]. Recent research demonstrates that when crop production - mostly corn - is reduced due to drought, a significant increase in migration from Mexico to the United States often follows [119]. Zacatecas is the Mexican state with the highest rates of migration to the United States [120].

Therefore, it is necessary to implement actions, strategies, and preventive and mitigation measures via public policies and social programs to reduce the vulnerability and risk of the rural sector to the presence and recurrence of drought events, especially considering the consequences of climate change. Although historically, different social groups in Mexico have had the ingenuity and organization to face drought [9-11], its adverse effects inevitably need to be systematically addressed using a proactive risk management approach $[13,116]$. In other words, state policies are needed for each of the affected sectors, especially agriculture, stockbreeding, and water resources [112]. The role of the state in the distribution of resources and the strengthening of local response capacities (under a proactive approach) is widely acknowledged as one of the most important determinants of the severity of the effects of drought [121,122]. In Mexico, drought is traditionally addressed using a reactive approach where the focus is facing the crisis rather than managing risk. When severe drought occurs, federal support is provided to affected farmers and livestock breeders via the Natural Disaster Fund (FONDEN) and the Fund to Support Population Affected by Climate Contingencies (FAPRACC), and state governments often implement emerging humanitarian and agricultural support programs-for example, the delivery of water by tankers to affected communities, food to rural populations, food supplements for livestock, and checks or cash to affected people - but all of these programs lack a welldefined and far-reaching purpose and, therefore, are not designed as comprehensive plans with specific strategies that could be replicated in future drought events $[12,13,116]$. As a result of the 2011-2012 drought, the federal government launched the National Program Against Drought (PRONACOSE), which sought to change the traditional approach to coping with the effects of this phenomenon by moving from reactive emergency responses to a proactive approach focused on risk management; the Mexican Drought Monitor (MSM) 
and the Drought Prevention and Mitigation Measures Programs (PMPMS) were created to support PRONACOSE in each of the 26 Watershed Councils into which the country is divided $[12,13,123]$. However, since their inception, these programs have lacked sufficient budgets and adequate follow-up strategies, mainly due to the constant rotation of the people responsible for their implementation in federal and state government agencies, and because there have been no severe drought conditions in the country in recent years.

On the other hand, although the Mexican Drought Monitor is useful to provide an overview of the national drought profile, it has several disadvantages that prevent it from being fully functional for real-time decision-making. First, it fails to use an objective and systematized method to assign specific weight to each of the indicators and indices comprising the MSM for the design of the drought map published every 2 weeks; therefore, the outlines of areas presenting drought responds to the criteria of the experts who design the maps. Additionally, the inclusion and combination of different types of drought indices (meteorological, agricultural, and hydrological) prevent the differentiation and recognition of the impact of the phenomenon on the different sectors of water users (industrial, urban public, farmers, etc.); this shortfall makes the system inadequate for decision-making in specific sectors such as agriculture, stockbreeding, or drinking water systems because it fails to consider the relationship between water supply and demand (water balance) for the different types of consumptive uses. The indices used to monitor vegetation conditions (VHI and NDVI) are useful to determine drought conditions in agriculture; however, these are based on satellite images and are not calibrated with field data (e.g., phenological stages of crops and sowing and harvesting dates), which makes it impossible to estimate the probability of agricultural drought or to issue timely warnings for the sector with any degree of reliability. For these reasons, we recommend the complementary use of specific tools for drought monitoring and early warning in agriculture, such as the FAO Country-Level ASIS system that we used in this research.

In this context, it is evident that much work remains to be completed in terms of reducing drought vulnerability and managing drought risk in Mexico, especially in rural areas where a significant part of the population lives and works and whose main economic activity is rainfed agriculture. Therefore, due to its economic and social relevance, this production activity must have adequate measures and strategies to cope with the high probability of significant drops in precipitation volumes expected as a result of climate change $[15,51,52,97,113]$. In this regard, some of the agricultural drought risk management and climate change adaptation strategies that must be adopted and implemented by public policies and government programs such as PRONACOSE or the various rural support programs are:

Improving the capabilities of the National Meteorological Service to conduct drought early-warning and monitoring activities by expanding and equipping the national network of weather stations, investing in state-of-the-art technology, and collaborating with national and international institutions to exchange and disseminate information;

Establishing a communication strategy to disseminate rainfall and drought seasonal early-warning measures for agriculture using different national and local media (radio, television, press, internet, etc.);

$\bigcirc \quad$ Promoting the modernization of production units by providing drought-tolerant improved seeds, fertilizers, and agrochemicals (preferably organic) for pest and weed control;

$\bigcirc \quad$ Promoting production reconversion in regions where water is scarce, i.e., encourage the use of crops and varieties with low water requirements to replace crops with higher demand;

- Providing technical assistance to production units by qualified technical staff to improve cultivation practices (sowing, fertilizing, harvesting, etc.) and help to optimize the use and management of available resources;

$\bigcirc \quad$ Encouraging the diversification of agricultural production systems by introducing forestry and livestock species (agro-silvopastoral systems); 
Promoting preventive grain storage for times of poor harvest;

Granting credit and insurance to agricultural production units, especially small producers, for the acquisition of adequate infrastructure and machinery to carry out their activities;

Facilitating the access of production units to local and regional markets by improving communication channels and transportation;

- Providing advice on the organization of production units to civil associations and commercial corporations so that they can have easier and faster access to loans and insurance provided by financial institutions.

\section{Conclusions}

Agricultural drought risk assessment is one of the fundamental pillars of integrated drought risk management. This article presents a method to conduct such assessment from an integrated perspective, that is, by emphasizing the combined role of hazard, exposure, and vulnerability to drought. This method is based on an objective analytical procedure that identifies which municipalities are at greatest risk in the event of agricultural drought. This information is especially useful for decision-makers and public policymakers to reduce the risk and vulnerability associated with drought.

The FAO ASIS-Country tool, used in this work to assess agricultural drought hazard (based on the VHI and ASI indices, and the DHI index proposed in this paper), when calibrated with field information at the state and municipal levels (crop coverage map, sowing and harvesting dates, and crop coefficients), allows for fairly accurate detection of periods of water stress, identifying the agricultural areas with the highest probability of drought occurrence, which are illustrated by maps that are easy for decision-makers to interpret. Likewise, the indices we developed in this work to assess drought exposure, vulnerability, and risk (DEI, DVI, and DRI) can be represented in maps that allow the rapid identification of municipalities with higher degrees of exposure, vulnerability, and risk in such a way that they are especially useful for those policymakers aimed at reducing the risk associated with drought. These indices and maps can also be useful for the timely implementation of drought mitigation and preventive measures such as the purchase of agricultural insurance, public or private investments in water harvesting systems, irrigation systems, water reserves, etc.

The state of Zacatecas was used as a case study. We confirmed that drought is one of the greatest threats to water and food security in the state due to its environmental and socioeconomic conditions. These conditions (among others: more than half of the territory is arid and the vast majority of production units lack adequate infrastructure, machinery, technical assistance, financing, and insurance to optimally carry out their production activities) make it particularly exposed and vulnerable to agricultural drought. These conditions are especially pronounced in the central and northern regions, where the agriculturally most important municipalities are located. These municipalities suffer from serious water imbalances when drought takes place, and highly rain-dependent sectors such as agriculture face frequent disasters.

Consequently, the implementation of actions, strategies, and preventive and mitigation measures to strengthen the water and food security of the state (and the country) must be further developed through public policies aimed at the integrated management of drought risk and adaptation to climate change. These actions will help to reduce the vulnerability of the state's population and production systems and to strengthen community and institutional capacities to cope with these climate anomalies.

Based on the experiences and limitations of this work, it is recommended that research related to the topic of agricultural drought risk management be carried out, taking into account some aspects that were not considered in this article, such as the following: generate various drought scenarios, i.e., model the possible behavior of agricultural production systems in the face of different degrees of water deficit; address and deepen the study of natural phenomena that explain climate variability (e.g., ENSO and PDO) and their 
relationship with agricultural drought; develop and apply methods for short- and mediumterm drought forecasting, as early warning tools for agriculture; in the case of irrigated agriculture, generate and implement models for optimizing water use, from supply sources to crops, including service costs, water conduction, and application efficiencies, etc.; among many other lines of research that could be implemented.

Supplementary Materials: The following are available online at https:/ /www.mdpi.com/article/10 .3390/w13101431/s1, Table S1: Municipalities that comprise the state of Zacatecas, Figures S1-S4: Fit of the GEV distribution to drought hazard, exposure, vulnerability, and risk indices, Figures S5-S7: Multicollinearity analysis of drought exposure, sensitivity, and adaptive capacity indicators.

Author Contributions: Conceptualization, methodology, and writing-original draft preparation, D.O.-G.; information gathering, data curation, and software management, J.A.C.-T., A.O.S. and H.V.C.-B.; project administration and funding acquisition, D.O.-G. All authors have read and agreed to the published version of the manuscript.

Funding: This research was funded by the National Council for Science and Technology (CONACYT), via the PDCPN-2017/4924 research project, Programa de Proyectos de Desarrollo Científico para atender Problemas Nacionales.

Institutional Review Board Statement: Not applicable.

Informed Consent Statement: Not applicable.

Data Availability Statement: Data on the mask of rainfed basic crops for study area are available at https:/ /www.gob.mx/siap/documentos/mapa-con-la-estimacion-de-superficie-sembrada-decultivos-basicos (accessed on 15 June 2020); data on the indicators used in this study are available at https://www.inegi.org.mx/programas/ccpv/2010/default.html\#Datos_abiertos (accessed on 5 June 2020), https:/ / www.inegi.org.mx/programas/ena/2017/ (accessed on 20 May 2020), and https://www.gob.mx/siap/documentos/siacon-ng-161430 (accessed on 23 August 2020); the tables and databases prepared with the detailed results obtained in this research are available upon request directly from the corresponding author.

Acknowledgments: We thank Oscar Rojas, Tamara Hernández, and Yanyun Li from FAO for providing the Country-Level ASIS, as well as the manuals, satellite information, and necessary support for its calibration and implementation in the state of Zacatecas.

Conflicts of Interest: The authors declare no conflict of interest. The funders had no role in the design of the study; in the collection, analyses, or interpretation of data; in the writing of the manuscript; or in the decision to publish the results.

\section{References}

1. World Meteorological Organization (WMO). Drought Monitoring and Early Warning: Concepts, Progress and Future Challenges; WMO: Geneva, Switzerland, 2006; p. 24.

2. Food and Agriculture Organization of the United Nations (FAO). The Impact of Disasters on Agriculture and Food Security; FAO: Rome, Italy, 2015; p. 77.

3. Wilhite, D.A. Drought as a natural hazard: Concepts and definitions. In Drought: A Global Assessment; Wilhite, D.A., Ed.; Routledge: London, UK, 2000; Volume 1, pp. 3-18.

4. Wilhite, D.A.; Glantz, M. Understanding the drought phenomenon: The role of definitions. Water Int. 1985, 10, 111-120. [CrossRef]

5. Heim, R.R. A review of twentieth-century drought indices used in the United States. Bull. Am. Meteorol. Soc. 2002, 83, 1149-1165. [CrossRef]

6. Hayes, M.J.; Alvord, C.; Lowrey, J. Drought indices. Interm. West Clim. Summ. 2007, 3, 2-6.

7. National Drought Mitigation Center (NDMC). Types of Drought. Available online: https://drought.unl.edu/Education/ DroughtIn-depth/TypesofDrought.aspx (accessed on 14 May 2020).

8. Wang, W.; Ertsen, M.W.; Svoboda, M.D.; Hafeez, M. Propagation of drought: From meteorological drought to agricultural and hydrological drought. Adv. Meteorol. 2016, 5. [CrossRef]

9. Florescano, E. Breve Historia De La Sequía En Mexico, 2nd ed.; CONACULTA: Mexico City, Mexico, $2000 ;$ p. 252.

10. García, A.V. Las sequías históricas de Mexico. Desastres Y Soc. 1993, 1, 2-18.

11. Ortega-Gaucin, D. Medidas para afrontar la sequía en Mexico: Una visión retrospectiva. Rev. De El Col. De San Luis 2018, 8 , 78-105. [CrossRef] 
12. Arreguín, C.F.; López, P.M.; Ortega-Gaucin, D.; Ibañez, H.O. La política pública para la sequía en Mexico: Avances, necesidades y perspectivas. Tecnol. Y Cienc. Del Agua 2016, 7, 63-76.

13. Ortega-Gaucin, D.; López, P.M.; Arreguín, C.F. Drought risk management in Mexico: Progress and challenges. Int. J. Saf. Secur. Eng. 2016, 6, 161-170. [CrossRef]

14. Centro Nacional de Prevención de Desastres (CENAPRED). Características E Impacto Socioeconómico De Los Principales Desastres Ocurridos En La República Mexicana En El Año 2011; Secretaría de Gobernación: Mexico City, Mexico, $2012 ;$ p. 403.

15. Salinas, P.J.A.; Colorado, R.G.; Maya, M.M.E. Escenarios de cambio climático para Mexico. In Atlas De Vulnerabilidad Hidrica En Mexico Ante El Cambio Climático; Arreguín, C.F.I., Ed.; IMTA: Jiutepec, Mexico, 2015; pp. 42-69.

16. Instituto Nacional de Ecología y Cambio Climático (INECC). Escenarios de Cambio Climático. Available online: https:/ /datos. gob.mx/busca/dataset/escenarios-de-cambio-climatico (accessed on 10 January 2020).

17. Instituto Nacional de Estadística y Geografía (INEGI) y Secretaría de Agricultura, Desarrollo Rural, Pesca y Alimentación (SAGARPA). Encuesta Nacional Agropecuaria 2014; Centro de Estudios para el Desarrollo Rural Sustentable y la Soberanía Alimentaria (CEDRSSA): Mexico City, Mexico, 2015; p. 24.

18. INEGI. Censo de Población y Vivienda 2010. Available online: https:/ / www.inegi.org.mx/programas/ccpv/2010/default.html\# Datos_abiertos (accessed on 5 June 2020).

19. INEGI. Encuesta Nacional Agropecuaria. 2017. Available online: https://www.inegi.org.mx/programas/ena/2017/ (accessed on 20 May 2020).

20. Ortega-Gaucin, D.; de la Cruz, B.J.; Castellano, B.H.V. Drought vulnerability indices in Mexico. Water 2018, 10, 1671. [CrossRef]

21. Diario Oficial de la Federación (DOF). Decreto Por El Que Se Crea El Organismo Seguridad Alimentaria Mexicana. Available online: https:/ / www.dof.gob.mx/nota_detalle.php?codigo=5548402\&fecha=18/01/2019 (accessed on 3 June 2020).

22. Van Loon, A.F.; Gleeson, T.; Clark, J.; van Dijk, A.I.J.M.; Stahl, K.; Hannaford, J.; Di Baldassarre, G.; Teuling, A.J.; Tallaksen, L.M.; Uijlenhoet, R.; et al. Drought in the anthropocene. Nat. Geosci. 2016, 9, 89-91. [CrossRef]

23. Sebesvari, Z.; Renaud, F.G.; Haas, S.; Tessler, Z.; Hagenlocher, M.; Kloos, J.; Szabo, S.; Tejedor, A.; Kuenzer, C. A review of vulnerability indicators for deltaic social-ecological systems. Sustain. Sci. 2016, 11, 575-590. [CrossRef]

24. Hohenthal, J.; Minoia, P. Social aspects of water scarcity and drought. In Handbook of Drought and Water Scarcity: Principle of Drought and Water Scarcity; Eslamian, S., Eslamian, F.A., Eds.; CRC Tailor \& Francis LTD Press: Abingdon, UK, 2017; pp. 607-626. [CrossRef]

25. World Meteorological Organization (WMO); Global Water Partnership (GWP). Handbook of Drought Indicators and Indices; Integrated Drought Management Programme (IDMP): Geneva, Switzerland, 2016; p. 45.

26. González, T.I.; Urquijo, J.; Blauhut, V.; Villarroya, F.; De Stefano, L. Learning from experience: A systematic review of assessments of vulnerability to drought. Nat. Hazards 2016, 80, 951-973. [CrossRef]

27. Zarafshani, K.; Sharafi, L.; Azadi, H.; Van Passel, S. Vulnerability assessment models to drought: Toward a conceptual framework. Sustainability 2016, 8, 588. [CrossRef]

28. Hagenlocher, M.; Meza, I.; Anderson, C.C.; Min, A.; Renaud, F.G.; Walz, Y.; Siebert, S.; Sebesvari, Z. Drought vulnerability and risk assessments: State of the art, persistent gaps, and research agenda. Environ. Res. Lett. 2019, 14. [CrossRef]

29. Carrao, H.; Naumann, G.; Barbosa, P. Mapping global patterns of drought risk: An empirical framework based on sub-national estimates of hazard, exposure and vulnerability. Glob. Environ. Chang. 2016, 39, 108-124. [CrossRef]

30. Zeng, Z.; Wu, W.; Li, Z.; Zhou, Y.; Guo, Y.; Huang, H. Agricultural drought risk assessment in southwest China. Water 2019, 11, 1064. [CrossRef]

31. Niu, K.; Hu, Q.; Zhao, L.; Jiang, S.; Yu, H.; Liang, C.; Wang, Y. Analysis of agricultural drought risk based on information distribution and diffusion methods in the main grain production areas of China. Atmosphere 2019, 10, 764. [CrossRef]

32. Meza, I.; Siebert, S.; Döll, P.; Kusche, J.; Herbert, C.; Eyshi Rezaei, E.; Nouri, H.; Gerdener, H.; Popat, E.; Frischen, J.; et al. Global-scale drought risk assessment for agricultural systems. Nat. Hazards Earth Syst. Sci. 2020, 20, 695-712. [CrossRef]

33. Frischen, J.; Meza, I.; Rupp, D.; Wietler, K.; Hagenlocher, M. Drought risk to agricultural systems in Zimbabwe: A spatial analysis of hazard, exposure, and vulnerability. Sustainability 2020, 12, 752. [CrossRef]

34. Guo, H.; Zhang, X.; Lian, F.; Gao, Y.; Lin, D.; Wang, J. Drought risk assessment based on vulnerability surfaces: A case study of maize. Sustainability 2016, 8, 813. [CrossRef]

35. Xie, Z.; Xu, J.; Deng, Y. Risk analysis and evaluation of agricultural drought disaster in the major grain-producing areas, China. Geomat. Nat. Hazards Risk 2016, 7, 1691-1706. [CrossRef]

36. Dabanli, I. Drought risk assessment by using drought hazard and vulnerability indexes. Nat. Hazards Earth Syst. Sci. Discuss. 2018. [CrossRef]

37. Ortega-Gaucin, D.; de la Cruz, B.J.; Castellano, B.H.V. Peligro, vulnerabilidad y riesgo por sequía en el contexto del cambio climático en Mexico. In Agua y Cambio Climático; Lobato, S.R., Pérez, A.A., Eds.; IMTA: Jiutepec, Mexico, 2018 ; pp. 78-103.

38. Ravelo, A.C.; Sanz, R.R.; Douriet, C.J.C. Detección, evaluación y pronóstico de las sequías en la región del Organismo de Cuenca Pacífico Norte, Mexico. AgriScientia 2014, 31, 11-24. [CrossRef]

39. Núñez-López, D.; Muñoz-Robles, C.A.; Reyes-Gómez, V.M.; Velasco-Velasco, I.; Gadsden-Esparza, H. Characterization of drought at different time scales in Chihuahua, Mexico. Agrociencia 2007, 41, 253-262.

40. Márdero, S.; Nickl, E.; Schmook, B.; Schneider, L.; Rogan, J.; Christman, Z.; Lawrence, D. Sequías en el sur de la península de Yucatán: Análisis de la variabilidad anual y estacional de la precipitación. Investig. Geográficas 2012, 78, 19-33. [CrossRef] 
41. Campos-Aranda, D.A. Estudio de sequías meteorológicas anuales por medio del índice de aridez, en el estado de Zacatecas, Mexico. Ing. Investig. Y Tecnol. 2016, 17, 405-417. [CrossRef]

42. Ortiz-Gómez, R.; Cardona-Díaz, J.C.; Ortiz-Robles, F.A.; Alvarado-Medellin, P. Caracterización de las sequías mediante la comparación de tres índices multiescalares en Zacatecas, Mexico. Tecnol. Y Cienc. Del Agua 2018, 9, 47-91. [CrossRef]

43. Collado, J.; Toledo, V. Localización óptima de estaciones climatológicas y observatorios meteorológicos en la República Mexicana. Ing. Hidráulica En Mexico 1997, 7, 47-64.

44. Guajardo, P.R.A.; Granados, R.G.R.; Sánchez, C.I.; Díaz, P.G.; Barbosa, M.F. Validación espacial de datos climatológicos y pruebas de homogeneidad: Caso Veracruz, Mexico. Tecnol. Y Cienc. Del Agua 2017, 8, 157-177. [CrossRef]

45. Belal, A.A.; El-Ramady, H.R.; Mohamed, E.S.; Saleh, A.M. Drought risk assessment using remote sensing and GIS techniques. Arab. J. Geosci. 2014, 7, 35-53. [CrossRef]

46. AghaKouchak, A.; Farahmand, A.; Melton, F.S.; Teixeira, J.; Anderson, M.C.; Wardlow, B.D.; Hain, C.R. Remote sensing of drought: Progress, challenges and opportunities. Rev. Geophys. 2015, 53, 452-480. [CrossRef]

47. Atzberger, C. Advances in remote sensing of agriculture: Context, description, existing operational monitoring systems and major information needs. Remote Sens. 2013, 5, 949-981. [CrossRef]

48. Comisión Nacional del Agua (CONAGUA). Análisis Espacial De Las Regiones Más Vulnerables Ante Las Sequías En Mexico; SEMARNAT: Mexico City, Mexico, 2012; p. 43.

49. Ortega-Gaucin, D. Sequía En Nuevo León: Vulnerabilidad, Impactos Y Estrategias De Mitigación; Instituto del Agua del Estado de Nuevo León (IANL): Apodaca, Mexico, 2012; p. 222.

50. Ortega-Gaucin, D.; de la Cruz, J.; Castellano, H.V. Economic, social and environmental vulnerability to drought in the Northwest River Basin System, Mexico. Int. J. Environ. Impacts 2018, 1, 240-253. [CrossRef]

51. Arreguín, C.F. Atlas De Vulnerabilidad Hídrica En Mexico Ante El Cambio Climático: Efectos Del Cambio Climático En El Recurso Hídrico De Mexico; IMTA: Jiutepec, Mexico, 2015; p. 148.

52. INECC. Atlas Nacional De Vulnerabilidad Al Cambio Climático; SEMARNAT: Mexico City, Mexico, 2019; p. 263.

53. Hernández, V.M.; García, J.G.; Orozco, B.H.; Juárez, O.M.G. Vulnerabilidad socioambiental del maíz nativo frente al cambio climático en el estado de Tlaxcala. Rev. Iberoam. Cienc. Biol. Agrop. 2018, 7, 53-76. [CrossRef]

54. Ahumada, C.R. Vulnerabilidad ante el cambio climático del sector agrícola del estado de Sinaloa. Cienc. Desde El Occidente 2018, 4, 8-19.

55. Luers, A.L.; Lobella, D.B.; Sklard, L.S.; Addamsa, C.L.; Matsona, P.A. A method for quantifying vulnerability, applied to the agricultural system of the Yaqui Valley, Mexico. Glob. Environ. Chang. 2003, 13, 255-267. [CrossRef]

56. Quijano, J.A.; Jaimes, M.A.; Torres, M.A.; Reinoso, E.; Castellanos, L.; Escamilla, J.; Ordas, M. Event-based approach for probabilistic agricultural drought risk assessment under rainfed conditions. Nat. Hazards 2015, 76, 1297-1318. [CrossRef]

57. Bojórquez-Serrano, J.I.; Álvarez-Bravo, A.; Vidal-Martínez, V.A.; Magaña-Rueda, V.; Marceleño-Flores, S. Modelo de vulnerabilidad y riesgo de la producción de maíz de temporal en Nayarit, Mexico. Rev. Mex. Cienc. Agríc. 2016, 13, 2475-2485. [CrossRef]

58. Bautista-Capetillo, C.; Carrillo, B.; Picazo, G.; Júnez-Ferreira, H. Drought assessment in Zacatecas, Mexico. Water 2016, 8, 416. [CrossRef]

59. Cardona, O. Estimación Holística Del Riesgo Sísmico Utilizando Sistemas Dinámicos Complejos. Ph.D. Thesis, Universitat Politècnica de Catalunya, Barcelona, Spain, 2001; p. 322.

60. Office of the United Nations Disaster Relief Coordinator (UNDRO). Natural Disasters and Vulnerability Analysis: Report of Expert Group Meeting (9-12 July 1979); UNDRO: Geneva, Switzerland, 1980; p. 48.

61. United Nations Office for Disaster Risk Reduction (UNISDR). Terminology on Disaster Risk Reduction; UNISDR: Geneva, Switzerland, 2009; p. 30.

62. Intergovernmental Panel on Climate Change (IPCC). Climate Change 2014: Impacts, Adaptation, and Vulnerability; Contribution of Working Group II to the Fifth Assessment Report of the IPCC; Cambridge University Press: Cambridge, UK, 2014 ; p. 157.

63. Magaña, V. Guía Metodológica Para La Evaluación De La Vulnerabilidad Ante Cambio Climático; INEGI y PNUD: Mexico City, Mexico, $2013 ;$ p. 61.

64. Walz, Y.; Dall, K.; Graw, V.; Villagran, L.J.C.; Kussul, N.; Jordaan, A. Understanding and Reducing Agricultural Drought Risk: Examples from South Africa and Ukraine, Policy Report No. 3; United Nations University-Institute for Environment and Human Security (UNU-EHS): Bonn, Germany, 2018; p. 30.

65. UNISDR. Report of the Open-Ended Intergovernmental Expert Working Group on Indicators and Terminology Relating to Disaster Risk Reduction; UNISDR: Geneva, Switzerland, 2016; p. 41.

66. World Bank (WB). Assessing Drought Hazard and Disk: Principles and Implementation Guidance; World Bank: Washington, DC, USA, 2019; p. 69.

67. Servicio de Información Agroalimentaria y Pesquera (SIAP); Sistema de Información Agroalimentaria de Consulta (SIACON). Available online: https:/ / www.gob.mx/siap/documentos/siacon-ng-161430 (accessed on 23 August 2020).

68. INEGI. Mapas Temáticos de Mexico. Available online: https:/ /www.inegi.org.mx/app/mapas /default.html?p=198\&ag=00 (accessed on 24 August 2020).

69. Rojas, O. Agricultural extreme drought assessment at global level using the FAO Agricultural Stress Index System (ASIS). Weather Clim. Extrem. 2020, 100184. [CrossRef]

70. Rojas, O. Country-Level ASIS: An Agricultural Drought Monitoring System; FAO: Rome, Italy, 2016; p. 8.

71. Kogan, F. Application of vegetation index and brightness temperature for drought detection. Adv. Space Res. 1995, 15, 91-100. [CrossRef]

72. Kogan, F. Global drought watch from space. Bull. Am. Met. Soc. 1997, 7, 621-636. [CrossRef] 
73. Kogan, F. Droughts of the late 1980's in the United States as derived from NOAA polar-orbiting satellite data. Bull. Am. Met. Soc. 1994, 76, 655-668. [CrossRef]

74. Rojas, O.; Vrieling, A.; Rembold, F. Assessing drought probability for agricultural areas in Africa with coarse resolution remote sensing imagery. Remote Sens. Env. 2011, 115, 343-352. [CrossRef]

75. Unganai, L.; Kogan, F. Drought monitoring and corn yield estimation in Southern Africa from AVHRR data. Remote Sens. Envrion. 1998, 63, 219-232. [CrossRef]

76. Li, Y.; Strapasson, A.; Rojas, O. Assessment of El Niño and La Niña impacts on China: Enhancing the early warning system on food and agriculture. Weater Clim. Extrem. 2020, 27, 100208. [CrossRef]

77. Ortega-Gaucin, D.; Ordoñez, A.; Rojas, O.; Hernéndez, T.; de la Cruz, J. Monitoreo Y Alerta Temprana De Sequía En La Agricultura: Evaluación Del Sistema Del Índice De Estrés Agrícola (Asis-País) De La Fao; Artículo COMEII-19024; FAO: Rome, Italy, 2019.

78. Van, H.R.; Eerens, H.; Haesen, D.; Royer, A.; Bydekerke, L.; Rojas, O.; Li, Y.; Racionzer, P. FAO's AVHRR-based Agricultural Stress Index System (ASIS) for global drought monitoring. Int. J. Remote Sens. 2016, 37, 418-439. [CrossRef]

79. Steduto, P.; Hsiao, T.; Fereres, E.; Raes, D. Crop Yield Response to Water; FAO Irrigation and Drainage Paper, No.; FAO: Rome, Italy, 2012; p. 501.

80. Hernández, T. Manual De Usuario Del Sistema Del Índice De Sequía Agrícola/ASIS País. Módulo II. Ejecución De La Herramienta ASIS País; FAO: Rome, Italy, 2018; p. 78.

81. Hernandez, T. Manual De Usuario Del Sistema Del Índice De Sequía Agrícola/ASIS País. Módulo I. Preparación De Datos Geográficos Para ASIS País; FAO: Rome, Italy, 2018; p. 72.

82. Rojas, O. Protocolo Para El Proceso De Calibración Y Adaptación Nacional De La Herramienta ASIS-País; FAO: Rome, Italy, 2016 ; p. 9.

83. SIAP. Mapa Con La Estimación De Superficie Sembrada De Cultivos Básicos. Available online: https://www.gob.mx/siap/ documentos / mapa-con-la-estimacion-de-superficie-sembrada-de-cultivos-basicos (accessed on 15 June 2020).

84. FAO. Evapotranspiración Del Cultivo: Guías Para La Determinación De Los Requerimientos De Agua De Los Cultivos; Estudio FAO Riego y Drenaje No. 56; FAO: Roma, Italy, 2006; p. 300.

85. Instituto Nacional de Investigaciones Forestales, Agrícolas y Pecuarias (INIFAP). Agenda Técnica Agrícola: Zacatecas; INIFAP: Mexico City, Mexico, 2017; p. 102.

86. INEGI. El Cultivo Del Frijol En Zacatecas: Censo Agropecuario 2007; INEGI: Aguascalientes, Mexico, 2013 ; p. 54.

87. Day, D.K.; Yan, J. (Eds.) Extreme Value Modeling and Risk Analysis: Methods and Applications; CRC Press: Boca Raton, FL, USA, $2016 ;$ p. 516.

88. Cardona, O.D. The need for rethinking the concepts of vulnerability and risk from a holistic perspective: A necessary review and criticism for effective risk management. In Mapping Vulnerability. Disasters, Development \& People; Bankoff, G., Frerks, G., Hilhorst, D., Eds.; Earthscan: London, UK, 2004; pp. 37-51.

89. Stathatou, P.M.; Kampragou, E.; Grigoropoulou, H.; Assimacopoulos, D.; Karavitis, C.; Porto, M.F.A.; Gironás, J.; Vanegas, M.; Reyna, S. Vulnerability of water systems: A comprehensive framework for its assessment and identification of adaptation strategies. Desalin. Water Treat. 2016, 57, 2243-2255. [CrossRef]

90. Monterroso, A.; Conde, C. Exposure to climate and climate change in Mexico. Geomat. Nat. Hazards Risk 2015, 6, 272-288. [CrossRef]

91. Orozco, I.; Martínez, A.; Ortega, V. Assessment of the water, environmental, economic and social vulnerability of a watershed to the potential effects of climate change and land use change. Water 2020, 12, 1682. [CrossRef]

92. Martín, M.Q.; Cabero, M.M.A.; Paz, S.Y.R. Tratamiento Estadístico De Datos Con SPSS. Prácticas Resueltas Y Comentadas; International Thompson Editores Espain: Madrid, Spain, 2015; p. 596.

93. Bernal, M.E. Bioestadística Básica Para Investigadores Con SPSS; Bubok Publishing S.L.: Madrid, Spain, 2014 ; p. 115.

94. Drewnowski, J.; Scott, W. The Level of Living Index; Report No. 4; United Nations Research Institute for Social Development (UNRISD): Geneva, Switzerland, 1966.

95. Iyengar, N.S.; Sudarshan, P. A method of classifying regions from multivariate data. Econ. Polit. Wkly. 1982, 17, $2047-2052$.

96. Rodríguez-González, B.; Pineda-Martínez, L.F.; Guerra-Cobián, V.H. Análisis de la variabilidad de las precipitaciones en el Estado de Zacatecas, Mexico, por medio de información satelital y pluviométrica. Ing. Investig. Y Tecnol. 2018, 19, 1-12. [CrossRef]

97. Herrera, T.C. Análisis Del Uso Y Manejo De Los Recursos Hídricos En El Estado De Zacatecas; Banco Mundial: Mexico City, Mexico, 2012; p. 76.

98. Galindo, G.G.; Tabares, R.W.C.; Gómez, A.G. Caracterización de productores agrícolas de seis distritos de desarrollo rural de Zacatecas. Terra Latinoam. 2000, 18, 83-92.

99. CENAPRED. Características E Impacto Socioeconómico De Los Principales Desastres Ocurridos En La República Mexicana En El Año 2005; Secretaría de Gobernación: Mexico City, Mexico, 2006; p. 492.

100. DOF. Declaratoria De Desastre Natural Por La Ocurrencia De Sequía Severa Del 1 De Mayo Al 30 De Noviembre De 2011 , En 42 Municipios Del Estado De Zacatecas. Available online: https: / /www.dof.gob.mx/nota_detalle.php?codigo=5227811\&fecha=03 /01/2012 (accessed on 26 August 2020).

101. DOF. Declaratoria De Desastre Natural A Consecuencia De La Sequía Atípica, Impredecible Y No Recurrente Del 1 De Junio Al 31 De Agosto Del 2011, En 52 Municipios De Zacatecas. Available online: https:/ / www.dof.gob.mx/nota_detalle.php?codigo=52 $61178 \&$ fecha $=26 / 07 / 2012$ (accessed on 26 August 2020).

102. Magallanes-Quintanar, R.; Blanco-Macías, F.; Galván-Tejada, E.C.; Galván-Tejada, J.; Márquez-Madrid, M.; Valdez-Cepeda, R.D. Negative regional Standardized Precipitation Index trends prevail in the Mexico's state of Zacatecas. Terra Latinoam. 2019, 37, 487-499. [CrossRef] 
103. Valdez-Cepeda, R.; Galván-Tejada, C.E.; Galván-Tejada, J.I.; Medina-García, G.; Blanco-Macías, F.; Méndez-Gallegos, S. de J.; Magallanes-Quintanar, R. Relationship between precipitation anomalies and multivariate ENSO index through wavelet coherence analysis. Atmósfera 2020, 33, 285-299. [CrossRef]

104. Segundo de, J.E. Índice Estandarizado De Precipitación (SPI) Y Su Relación Con Superficie Agrícola Siniestrada En El Estado De Zacatecas. Master's Thesis, UNAM, Mexico City, Mexico, 2018; p. 145.

105. Carrillo-Martínez, C.J.; Álvarez-Fuentes, G.; Aguilar-Benítez, G.; García-López, J.C.; Contreras-Servín, C. Rentabilidad de la producción de frijol (Phaseolus vulgaris L.), maíz (Zea mays L.) y chile (Capsicum annuum) en el municipio de Morelos, Zacatecas. Acta Univ. 2019, 29, e1984. [CrossRef]

106. Adame, C.A.; Pérez, E.A.A.; Chavez, R.L. Los productores y la producción agrícola de temporal en la región Río GrandeSombrerete, Zacatecas. In Teoría, Impactos Externos Y Políticas Públicas Para El Desarrollo Regional; UNAM: Mexico City, Mexico, 2018; pp. 355-377.

107. Secretaría de Agricultura y Desarrollo Rural (SADER). Reporte Del Mercado De Frijol. Available online: https://www.cima. aserca.gob.mx/work/models/cima/pdf/cadena/2019/Reporte_mercado_frijol_180219.pdf (accessed on 20 September 2020).

108. Pita, O.; Ortega-Gaucin, D. Analysis of anomalies and trends of climate change indices in Zacatecas, Mexico. Climate 2020, 8, 4. [CrossRef]

109. Conde, C.; Ferrer, R.; Araujo, R. El Niño en el sector agrícola. In Los Impactos Del Niño En Mexico; Magaña, V., Ed.; UNAM-Secretaría de Gobernación: Mexico City, Mexico, 2004; pp. 103-136.

110. Ortega-Gaucin, D. El peligro por sequía en Mexico. In Seguridad Hídrica; Tzatchcov, V.G., Ed.; IMTA: Jiutepec, Mexico, 2020; pp. 164-189.

111. Rojas, O.; Li, Y.; Cumani, R. Understanding the Drought Impact of El Niño on the Global Agricultural Areas: An Assessment Using FAO's Agricultural Stress Index (ASI); FAO: Rome, Italy, 2014; p. 42. [CrossRef]

112. Conde, C. Mexico Y El Cambio Climático Global; SEMARNAT: Mexico City, Mexico, 2011; p. 23.

113. Adger, W.N.; Arnell, N.W.; Tompkins, E.L. Adapting to climate change: Perspectives across scales. Glob. Environ. Chang. 2005, 15, 75-76. [CrossRef]

114. Fan, X.; Fei, C.; McCarl, B. Adaptation: An Agricultural Challenge. Climate 2017, 5, 56. [CrossRef]

115. FAO. Towards a Water and Food Secure Future: Critical Perspectives for Policy-Makers; FAO \& World Water Council: Rome, Italy; Marseille, France, 2015.

116. Ortega-Gaucin, D. Sequía en Mexico y Estados Unidos de América: Diferencias esenciales de vulnerabilidad y enfoques en la atención al fenómeno. Front. Norte 2014, 26, 141-148.

117. Vásquez-León, M.; West, C.T.; Finan, T.J. A comparative assessment of climate vulnerability: Agriculture and ranching on both sides of the US-Mexico border. Glob. Environ. Chang. 2003, 13, 159-173. [CrossRef]

118. Velasco, I.; Ochoa, L.; Gutiérrez, C. Sequía, un problema de perspectiva y gestión. Región Y Soc. 2005, 17, 35-71. [CrossRef]

119. Feng, S.; Krueger, A.B.; Oppenheimer, M. Linkages among climate change, crop yields and Mexico-US cross-border migration. Proc. Natl. Acad. Sci. USA 2010, 107, 14257-14262. [CrossRef] [PubMed]

120. Comisión Nacional de Población (CONAPO). Índice de Intensidad Migratoria, Mexico-Estados Unidos. Available online: http: //www.conapo.gob.mx/es/CONAPO/Indice_de_Intensidad_Migratoria_Mexico_-_Estados_Unidos (accessed on 8 September 2020).

121. Agrawal, A. Local institutions and adaptation to climate change. In Social Dimensions of Climate Change; Mearns, R., Norton, A., Eds.; The World Bank: Washington, DC, USA, 2010; pp. 173-197.

122. Eakin, H.; Lemos, M.C. Adaptation and the state: Latin America and the challenge of capacity-building under globalization. Glob. Environ. Chang. 2006, 16, 7-18. [CrossRef]

123. Ortega-Gaucin, D.; Velasco, I. Program of preventive and mitigation drought measures in the Rio Balsas Basin Council, Mexico. In Drought: Research and Science-Policy Interfacing; Andreu, J., Ed.; CRC Press/Balkema: Boca Raton, FL, USA, 2015 ; pp. 493-498. 